\title{
The role of the aryl hydrocarbon receptor in the development of cells with the molecular and functional characteristics of cancer stem-like cells
}

\author{
Elizabeth A. Stanford ${ }^{1,2}$, Zhongyan Wang ${ }^{1}$, Olga Novikov ${ }^{1,2}$, Francesca Mulas ${ }^{3}$, Esther Landesman-Bollag ${ }^{4}$, \\ Stefano Monti ${ }^{3}$, Brenden W. Smith ${ }^{2,4,5}$, David C. Seldin ${ }^{4}$, George J. Murphy ${ }^{4,5}$ and David H. Sherr ${ }^{{ }^{*}}$
}

\begin{abstract}
Background: Self-renewing, chemoresistant breast cancer stem cells are believed to contribute significantly to cancer invasion, migration and patient relapse. Therefore, the identification of signaling pathways that regulate the acquisition of stem-like qualities is an important step towards understanding why patients relapse and towards development of novel therapeutics that specifically target cancer stem cell vulnerabilities. Recent studies identified a role for the aryl hydrocarbon receptor (AHR), an environmental carcinogen receptor implicated in cancer initiation, in normal tissue-specific stem cell self-renewal. These studies inspired the hypothesis that the AHR plays a role in the acquisition of cancer stem cell-like qualities.

Results: To test this hypothesis, AHR activity in Hs578T triple negative and SUM149 inflammatory breast cancer cells were modulated with AHR ligands, shRNA or AHR-specific inhibitors, and phenotypic, genomic and functional stem cell-associated characteristics were evaluated. The data demonstrate that (1) ALDH ${ }^{\text {high }}$ cells express elevated levels of Ahr and Cyp1b1 and Cyp1a1, AHR-driven genes, (2) AHR knockdown reduces ALDH activity by $80 \%$, (3) AHR hyper-activation with several ligands, including environmental ligands, significantly increases ALDH1 activity, expression of stem cell- and invasion/migration-associated genes, and accelerates cell migration, (4) a significant correlation between Ahr or Cyp 161 expression (as a surrogate marker for AHR activity) and expression of stem cell- and invasion/migration-associated gene sets is seen with genomic data obtained from 79 human breast cancer cell lines and over 1,850 primary human breast cancers, (5) the AHR interacts directly with Sox2, a master regulator of self-renewal; AHR ligands increase this interaction and nuclear SOX2 translocation, (6) AHR knockdown inhibits tumorsphere formation in low adherence conditions, (7) AHR inhibition blocks the rapid migration of ALDH ${ }^{\text {high }}$ cells and reduces ALDH high cell chemoresistance, (8) ALDH ${ }^{\text {high }}$ cells are highly efficient at initiating tumors in orthotopic xenografts, and (9) AHR knockdown inhibits tumor initiation and reduces tumor Aldh1a1, Sox2, and Cyp1b1 expression in vivo.
\end{abstract}

Conclusions: These data suggest that the AHR plays an important role in development of cells with cancer stem cell-like qualities and that environmental AHR ligands may exacerbate breast cancer by enhancing expression of these properties.

Keywords: Aryl hydrocarbon receptor, Breast cancer, Environment, Sox2, Tumor initiating cells

\footnotetext{
* Correspondence: dsherr@bu.edu

'Deceased

'Department of Environmental Health, Boston University School of Public

Health, 72 East Concord Street (R-408), Boston, Massachusetts 02118, USA

Full list of author information is available at the end of the article
} 


\section{Background}

Given the emerging evidence that common environmental carcinogens play a significant role in cancer [1], increased attention has been paid to molecular mechanisms through which pollutants affect tumor formation, invasion and/or progression [2-4]. Historically, most studies on environmental chemical carcinogenesis centered on the ability of genotoxic chemicals to damage DNA, induce mutations, and initiate cancers [5-7]. However, recent data suggest alternative, non-genotoxic pathways involving cellular receptors that can be activated by environmental ligands. One such receptor is the aryl hydrocarbon receptor (AHR). The AHR is the only ligand-activated member of the Per-ARNT-Sim (bHLH/PAS) family of transcription factors, all of which play important roles as environmental- and physiological stress-sensing proteins [8]. The AHR has been best studied for its ability to be activated by dioxins, polychlorinated biphenyls, and polycyclic aromatic hydrocarbons [9], all of which are high priority chemicals on the U.S. Agency for Toxic Substances and Disease Registry list of pollutants of greatest concern to human health (http://www.atsdr.cdc.gov/SPL/resources).

Ligand-bound AHR induces P450 enzymes such as CYP1B1 and CYP1A1, which are capable of generating mutagenic intermediates. However, more recent work suggests that the AHR, which is expressed at aberrantly high levels and is chronically active in several cancers, plays an ongoing role in tumor progression by enhancing tumor invasion and migration [10-15]. The contribution of the AHR to the later stages of cancer may be mediated by non-genotoxic endogenous ligands, which chronically drive AHR transcriptional activity $[16,17]$. Here, it is postulated that environmental ligands mimic this effect and drive cancer progression, at least in part, by increasing the development and/or function of cells exhibiting cancer stem-like cell $\left(\mathrm{CS}_{\mathrm{L}} \mathrm{C}\right)$ properties.

Recent evidence suggests that invasion and eventual metastasis leading to patient death is mediated, to a disproportionate extent, by chemoresistant, long-lived cancer stem cells, sometimes referred to as tumor-initiating cells [18-25]. Breast cancer stem cells can be defined by (1) expression of genes associated with 'normal' tissue stem cells (e.g. Notch1,2, Sox2, Pou5F1/Oct4) and with invasion and migration (e.g. Twist1,2, Vim, Snai1, Snai2) [26-30]; (2) formation of spheroid colonies in ultra-low adherence cultures [31]; (3) elevated levels of aldehyde dehydrogenases (ALDH), enzymes associated with chemoresistance, high histological tumor grade, and poor prognoses [19, 21, 32]; (4) the propensity to self-renew while spawning progenitor cells [31,33]; and (5) an increased tumor initiation capacity in xenografts [31, 33]. Here, we operationally define 'breast cancer stem-like cells' $\left(\mathrm{BCS}_{\mathrm{L}} \mathrm{C}\right)$ as tumor cells robustly expressing the five aforementioned characteristics in a continuum of 'stem- ness' in which some cells are more stem-like than others at any given time. Clearly, identifying factors responsible for the development of cells with cancer stem cell qualities is an important step towards understanding why many patients relapse, even several years after remission.

The AHR plays an important role in tissue-specific embryonic development, hematopoietic stem cell selfrenewal, pluripotent stem cell and neural stem cell differentiation, and megakaryocyte/erythroid stem cell growth [34-40]. Here, complementing parameters of 'stem-ness', including ALDH enzyme activity, stem cell-, invasionand migration-associated gene expression, tumorsphere formation, migration rate, chemoresistance, and tumor formation at limiting concentrations in xenografts were assessed to test the hypothesis that the AHR similarly influences development and function of $\mathrm{BCS}_{\mathrm{L}} \mathrm{Cs}$. The potential for the AHR to directly interact with the Sox2 gene, a master regulator of normal tissue-specific stem cell selfrenewal and differentiation, was of particular interest.

These studies were performed primarily with $\mathrm{ER}^{-} / \mathrm{PR}$ - $/$ Her2 ${ }^{-}$triple negative breast cancer (TNBC) cell lines: Hs578T, derived from a carcinomosarcoma, and SUM149, derived from an inflammatory breast cancer (IBC). TNBC lines were selected for these studies primarily because no effective targeted therapeutic is yet available for this class of breast cancers and because we wanted to evaluate AHR signaling in the absence of its well-established interactions with the estrogen receptor [41]. Results in those lines were compared with genomic outcomes in 79 breast cancer cell lines and more than 1,850 primary cancers. Our results show that the AHR is involved in the control of phenotypic, genomic, and functional cancer stem cell markers in $\mathrm{ER}^{-} / \mathrm{PR}^{-} / \mathrm{Her} 2^{-}$cells, strongly implicating an important role for the AHR in acquisition of stem cell-like qualities, encouraging development of AHR-targeted therapeutics, and raising the possibility that environmental AHR ligands may drive $\mathrm{BCS}_{\mathrm{L}} \mathrm{C}$ development or activity.

\section{Results \\ AHR expression is elevated in ALDH $1^{\text {high }}$ TNBCs}

We have previously published data demonstrating elevated expression of transcriptionally ('constitutively') active AHR in human breast cancer cell lines [10, 15, $42,43]$. The expression of nuclear $\mathrm{AHR}$ in $\mathrm{ER}^{-} / \mathrm{PR}^{-} / \mathrm{Her} 2^{-}$ human breast cancer-derived Hs578T cells and in inflammatory $\mathrm{ER}^{-} / \mathrm{PR}^{-} / \mathrm{Her} 2^{-}$breast cancer-derived SUM149 cells (Additional file 1: Figure S1A) was consistent with these reports. Furthermore, a predominance of nuclear AHR in primary human breast cancers (Additional file 1: Figure S1B, middle and bottom panels), but not in normal breast tissue (Additional file 1: Figure S1B, top panel), supports the conclusion that the AHR is constitutively active in primary cancers as well. Importantly, non-epithelial cells did not express AHR, normal epithelial cells in ducts had a 
low level of AHR staining, similar to our previous findings in rats [44], and all AHR staining seen in normal epithelial cells was cytoplasmic, indicating inactive AHR. Note that the stains presented here are representative of similar staining observed in 50 human breast cancer samples fixed on a tissue microarray.

Work from several laboratories indicates a role for the AHR in tissue-specific stem cell development [34-38], suggesting a general role for the AHR in stem cell biology. We and others have demonstrated that the AHR is highly expressed and constitutively active in breast cancers and that its activity correlates with tumor aggressiveness [10, 44-47]. Since cancer stem cells contribute to tumor progression, we postulated that the AHR plays a role in the development of breast cancer cells with stem cell-like characteristics $\left(\mathrm{BCS}_{\mathrm{L}} \mathrm{C}\right)$.

Several investigators have shown that $\mathrm{CD} 44^{+} / \mathrm{CD} 24^{-}$ cell staining is not an entirely consistent indicator of tumor initiating ability in $\mathrm{ER}^{-} / \mathrm{PR}^{-} / \mathrm{Her}^{-}$breast cancer cells due to over-staining of TNBCs [23, 48-51]. Overexpression or non-specific staining for these prototypic cancer stem cell markers also precluded their use in our studies (data not shown). Therefore, ALDH activity, which appears to be a more selective functional marker for TNBC stem-like cells [19, 23, 52, 53], was used here for marking of and enriching for cancer stem-like cells.

A fluorescence-based ALDH1 enzyme activity assay $[19,20,23,52,53]$ was used to quantify ALDH1 activity in TNBC Hs578T cells, which express relatively high levels of transcriptionally active AHR [15]. Cells were sorted by flow cytometry into ALDH $1^{\text {high }}$ and ALDH1 $1^{\text {low }}$ subsets. Approximately $5 \%$ of Hs578T cells expressed high levels of ALDH1 activity (ALDH ${ }^{\text {high }}$; Fig. 1a, right panel), a result consistent with previous studies of $\mathrm{BCS}_{\mathrm{L}} \mathrm{Cs}$
[20]. To determine if the $A h r$ and an AHR target gene, Cyp1b1, are more highly represented in ALDH ${ }^{\text {high }}$ cells, $A h r$ and Cyp $1 b 1$ mRNAs were quantified by RT-qPCR. Ahr and Cyp1b1 mRNAs were significantly higher in ALDH ${ }^{\text {high }}$ cells than ALDH ${ }^{\text {low }}$ cells $(P<0.05-0.005$; Fig. $1 b)$.

To determine if elevated $A h r$ and Cyp $1 b 1$ expression in ALDH $1^{\text {high }}$ cells reflects a role for the AHR in maintaining stem cell properties and if environmental AHR ligands have the potential to increase these properties in TNBCs, AHR expression or activity was modulated with a doxycycline (dox)-inducible $A h r$-specific shRNA (shAhr), AHR inhibitors (CH223191 and CB7993113) [42, 54, 55], or four AHR agonists: (1) 6-formylindolo[3,2-b]carbazole (FICZ), a high affinity AHR ligand, tryptophan photometabolite, and potential endogenous ligand [56]; (2) $\beta$-naphthoflavone ( $\beta$-NF), a flavone with moderate affinity for the AHR; (3) 2,3,7,8-tetrachlorodibenzo( $p$ )dioxin (TCDD), a high affinity, persistent environmental AHR ligand and 'gold standard' AHR ligand; or (4) 7,12 dimethylbenzanthracene (DMBA), a readily metabolizable polycyclic aromatic hydrocarbon.

Dox-induced shAhr or the AHR-specific inhibitor CH223191 significantly reduced $(P<0.01-0.0001) A h r$ expression and AHR-dependent ( $p G u d L u c)$ reporter activity, respectively (Fig. 2a), significantly decreased $(P<0.05-$ $0.0005)$ the percentage of ALDH ${ }^{\text {high }}$ cells by over $80 \%$ (Fig. 2b, c), and reduced overall ALDH1 activity in the entire Hs578T population (Fig. 2d), suggesting that 'constitutively active' (endogenous ligand-activated) AHR maintains baseline ALDH1 levels. Similar data were obtained with our recently described AHR inhibitor, CB7993113 [42] (not shown). Conversely, FICZ, $\beta-\mathrm{NF}$, TCDD, or DMBA significantly increased the percentage of ALDH $1{ }^{\text {high }}$ cells and ALDH1 activity in the entire Hs578T population
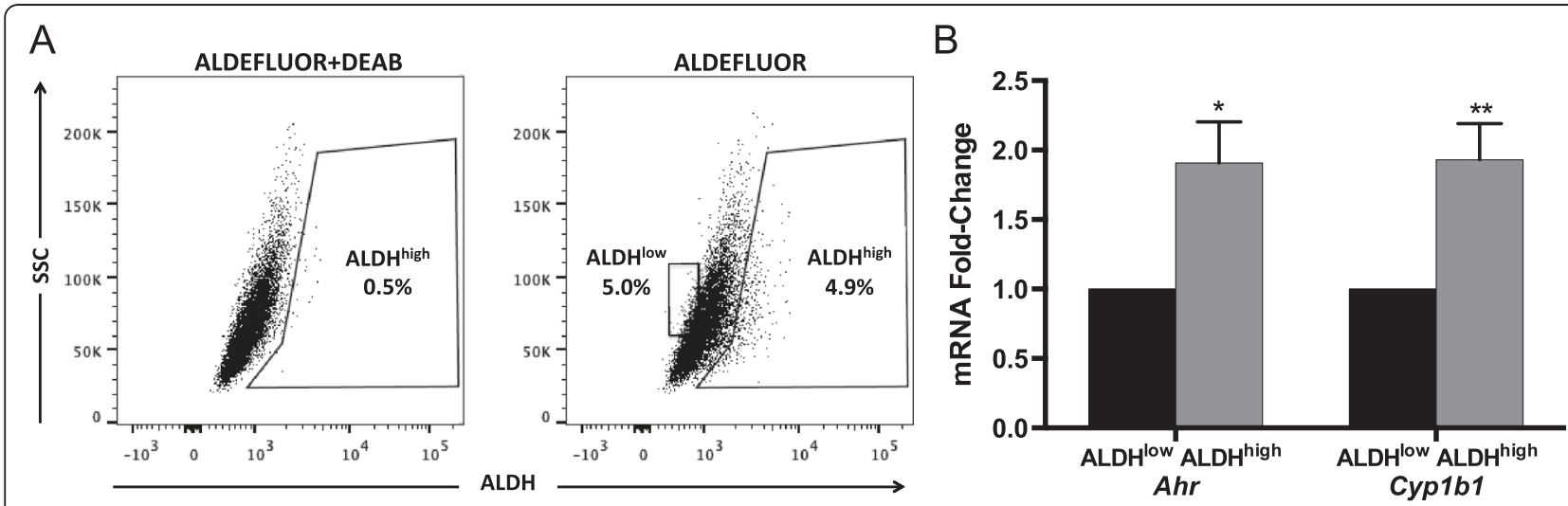

Fig. 1 Ahr and Cyp 161 expression is increased in ALDH1 ${ }^{\text {high }}$ Hs578T cells. (a) ER $/$ PR $^{-} / H E R 2^{-}$Hs578T cells were stained with ALDEFLUOR ${ }^{\text {TM }}$ in the presence or absence of diethylaminobenzaldehyde (DEAB), a specific ALDH inhibitor, and ALDH activity (production of fluorescent substrate) was quantified by flow cytometry. Regions were set using dot plots from DEAB-treated cells. Data are representative of 24 experiments. (b) Ahr and Cyp1b1 mRNA expression in sorted ALDH high and ALDH ${ }^{\text {low }}$ cells was quantified by RT-qPCR. Data from three independent experiments were analyzed using the Pfaffl method [103], normalized to the Gapdh signal, and presented as mean fold-change from ALDH ${ }^{\text {low }} \pm$ standard error. Asterisks indicate a significant increase in the mRNA fold-change, ${ }^{*} P<0.05,{ }^{*} P<0.005$ 


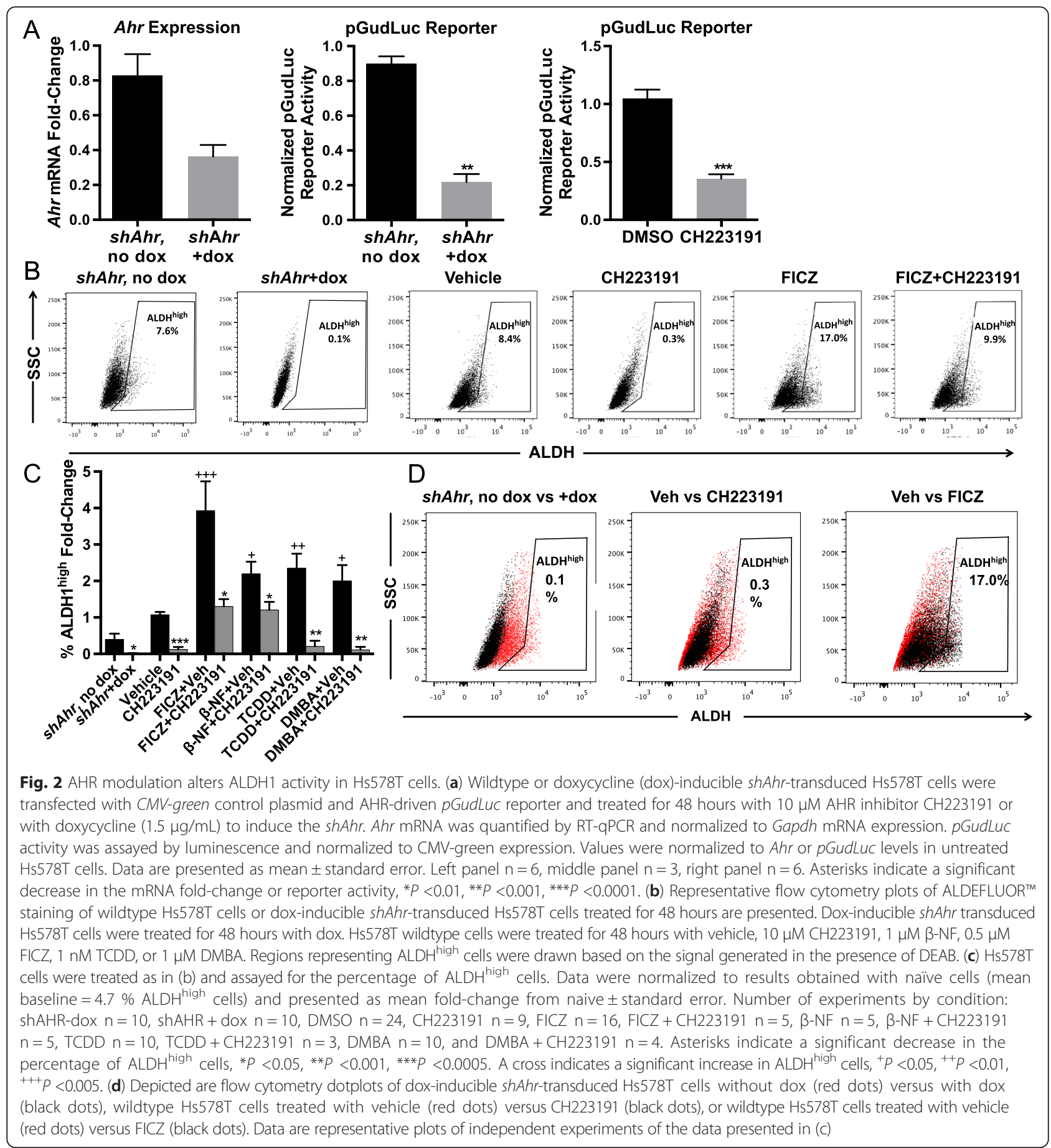

( $P<0.05-0.005$; Fig. 2b,c, d). In all cases, AHR agonist-induced increases were significantly inhibited by $\mathrm{CH} 223191(P<0.05-0.001)$. Similar results were obtained with immortalized but non-malignant triple negative MCF-10F cells (Additional file 2: Figure S2) and with $\mathrm{ER}^{+}$luminal-type MCF7 cells [57] (data not shown). These results suggest that AHR ligandinduced ALDH up-regulation is likely generalizable to different breast cancer subtypes.
Increasing AHR activity increases expression of $\mathrm{BCS}_{\mathrm{L}} \mathrm{C}-$ related genes

To determine if several stem cell-associated genes are regulated by the AHR, Hs578T cells were treated for 48 hours with vehicle or FICZ, stained with ALDEFLUOR ${ }^{\mathrm{TM}}$, and sorted for ALDH ${ }^{\text {high }}$ and ALDH ${ }^{\text {low }}$ cells. Consistent with previous studies demonstrating $\mathrm{BCS}_{\mathrm{L}} \mathrm{C}$ plasticity [58], presorting $\mathrm{Hs} 578 \mathrm{~T} \mathrm{ALDH}^{\text {high }}$ and $\mathrm{ALDH}^{\text {low }}$ cells prior to treatment and culture for 48 hours was precluded by the 
tendency for sorted Hs578T subpopulations to revert to the original distribution of $\mathrm{ALDH}^{\text {high }}(\sim 5 \%)$ and $\mathrm{ALDH}^{\text {low }}$ ( $95 \%$ ) cells within 24 hours (data not shown).

As expected, vehicle-treated ALDH ${ }^{\text {high }}$ cells produced higher levels of Aldh1a1, Ahr, Cyp1b1, and Cypla1 than vehicle-treated ALDH ${ }^{\text {low }}$ cells $(P<0.005$; Fig. $3 a)$. Aldh $3 a 1$ mRNA, previously associated with AHR activity [59], was not detected ( $>33$ cycles) in either vehicle or AHR agonist (FICZ or $\beta$-naphthoflavone)-treated Hs578T cells (data not shown). $\mathrm{ALDH}^{\text {high }}$ cells also expressed significantly higher levels of seven of the eight stem cell-associated genes studied $(P<0.05-0.005)$ with $M s i 1$ being the exception (Fig. 3a). As expected from the ALDH enzyme activity assay (Fig. 2), FICZ treatment increased Aldh1a1, Cyp1b1, and Cypla1 expression in both $\mathrm{ALDH}^{\text {low }}$ and ALDH $^{\text {high }}$ cells $(P<0.05-0.01$; Fig. $3 b, c)$. Consistent with previous studies, AHR ligand induced significantly higher levels of Cyp1a1 than Cyp1b1 $(P<0.05)$, while baseline Cyp1b1 levels tended to be higher than Cyp1a1 levels [15]. FICZ also increased expression of seven of eight stem cell-associated genes in both cell subsets $(P<0.05-0.005)$, again with Msi1 being the outlier (Fig. 3b, c). These results support the hypothesis that constitutively active and/or exogenous agonist-induced AHR up-regulates multiple stem cell-associated genes. Several of these genes express multiple consensus AHR response elements (Table 1), suggesting that they may be directly regulated by the AHR.

Given the pivotal role for Sox2 in stem cell selfrenewal, $\mathrm{BCS}_{\mathrm{L}} \mathrm{C}$ development and breast cancer outcomes [27, 60-63], AHR/Sox2-specific ChIP assays were performed to determine if the AHR directly interacts with the Sox 2 promoter. ChIP assays measuring AHRCyp $1 b 1$ promoter binding served as positive controls [15]. Indeed, there was a significant basal level of AHR binding to both Cyp1b1 and Sox 2 promoter fragments $(P<0.005$; Fig. 4a), each of which contains several AHR response elements within $500 \mathrm{bp}$ of the PCR primer binding sites (Table 1). AHR inhibition with $\mathrm{CH} 223191$ significantly decreased AHR-Sox2 and AHR-Cyp $1 b 1$ binding $(P<0.05)$. AHR hyper-activation with FICZ significantly increased AHR-Cyp $1 b 1$ and AHR-Sox2 binding by approximately 3 -fold and 2 -fold, respectively $(P<0.05)$. The AHR-Sox2 increase was blocked with CH223191 treatment $(P<0.05$; Fig. 4a). Furthermore, treatment of SUM149 cells or MCF-7 cells, which are known to express relatively high SOX2 levels [64], with FICZ, TCDD, or $\beta$-NF consistently increased nuclear SOX2 (Fig. 4b, c), a result consistent with increased levels of transcriptionally active SOX2
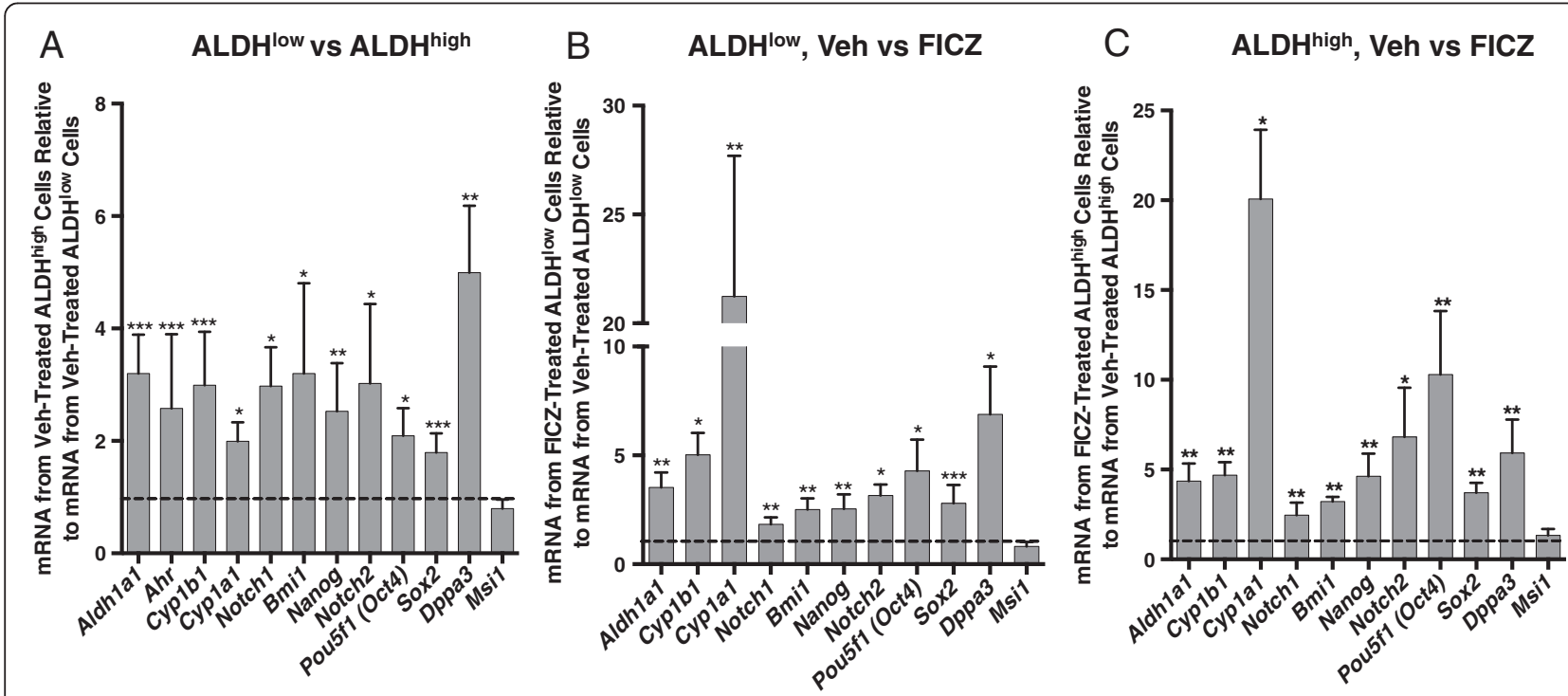

Fig. 3 AHR hyper-activation increases expression of stem cell-associated genes. Hs578T cells were treated with vehicle or $0.5 \mu \mathrm{M}$ FICZ for 48 hours, sorted into $\mathrm{ALDH}^{\text {high }}$ and $\mathrm{ALDH}{ }^{\text {low }}$ cell populations, and then assayed by RT-qPCR for the relative levels of the eight stem cell-associated genes indicated. Gene expression was then normalized to Gapdh levels and fold-change from vehicle-treated ALDH ${ }^{\text {low }}$ or ALDH high cells was calculated. Data from nine independent experiments are presented as the mean fold-change \pm standard error for all genes except for Cyplal, in which six independent experiments are presented. In all cases, statistical significance was determined with the Wilcoxon rank sum test to determine if the distributions of results, relative to 1 as the standard (represented by the dotted line on each graph), are different between the comparison groups. Asterisks indicate a significant increase in the mRNA fold-change, ${ }^{*} P<0.05,{ }^{* *} P<0.01,{ }^{* * *} P<0.005$. (a) Expression levels of stem cell-associated genes were normalized to expression levels in vehicle-treated $\mathrm{ALDH}^{\mathrm{low}}$ cells and the distribution of outcomes from vehicle-treated ALDH ${ }^{\text {high }}$ versus vehicle-treated $\mathrm{ALDH}^{\mathrm{low}}$ cells compared. (b) Stem cell-associated gene expression levels were normalized to expression levels in vehicle-treated ALDH ${ }^{\text {low }}$ cells and the distribution of outcomes from vehicle-treated ALDH ${ }^{\text {low }}$ versus FICZ-treated ALDH ${ }^{\text {low }}$ cells was compared. (c) Stem cell-associated gene expression levels were normalized to expression levels in vehicle-treated ALDH ${ }^{\text {high }}$ cells and the distribution of outcomes from vehicle-treated $\mathrm{ALDH}^{\text {high }}$ versus FICZ-treated ALDH ${ }^{\text {high }}$ cells was compared 
Table 1 Consensus aryl hydrocarbon receptor response elements (AHREs) in human stem cell- and migration/invasion-associated gene promoters

\begin{tabular}{lll}
\hline & Gene & \# of Consensus AHREs and location relative to TSS \\
\hline Standard & Cyplb1 & $8(-206,-267,-840,-859,-944,-1028,-1678,-2392)$ \\
Stem cell markers & Aldh1a1 & 0 \\
Sox2 & $7(-617,-749,-1284,-1430,-1678,-2577,+59)$ \\
Nanog & $9(-83,-140,-169,-430,-683,-1076,-2019,-2103,+146)$ \\
Dppa3 & NA \\
Pousf1 & $3(-1403,-2203,-2289)$ \\
Bmi1 & $5(-64,328,-369,-2275,-2428)$ \\
& Notch1 & $13(-75,-284,-367,-655,-743,-982,-1270,-1838,-1844,-2114,-2140,+52,+196)$ \\
Notch2 & NA \\
Msi1 & $7(-270,-559,-904,-1821,-2114,-2686,+190)$ \\
Snai1 & $5(-82,-148,-1836,-1944,+216)$ \\
Twist & NA \\
Vim & $6(-360,384,-927,-1003,+224,+294)$ \\
Twist2 & $2(-314,-2114)$ \\
Tgfb1 & $5(-836,-1936,-2037,-2190,-2734)$ \\
Snair & $5(-576,-2016,-2821,-2823,+50)$ \\
Fn1 & $1(-2023)$ \\
\hline
\end{tabular}

Consensus AHREs were searched up to 3,000 bp upstream and $300 \mathrm{bp}$ upstream of the transcription start site using Transcriptional Regulatory Element Database (http://rulai.cshl.edu)

following AHR hyper-activation. Finally, ectopic Sox2 expression significantly increased ALDH1 activity $(P<0.005$; Fig. 4d). These data strongly suggest that the AHR directly interacts with Sox2, a critical $\mathrm{BCS}_{\mathrm{L}} \mathrm{C}$-associated gene, which in turn regulates ALDH1 expression, an enzyme associated with chemoresistance [53].

Increasing AHR activity increases expression of migrationand invasion-associated genes

$\mathrm{BCS}_{\mathrm{L}} \mathrm{Cs}$ are more invasive than the bulk tumor population and have increased expression of migration- and invasion-associated markers [21, 22, 28, 29, 53, 58, 65]. To determine if the increase in stem cell markers described above correlates with markers of migration and invasion, Hs578T cells were treated with vehicle or FICZ for 48 hours, sorted for ALDH ${ }^{\text {high }}$ and ALDH ${ }^{\text {low }}$ cells, and evaluated for expression of seven genes associated with increased tumor migration and/or invasion. As seen for stem cell markers (Fig. 3), ALDH ${ }^{\text {high }}$ cells expressed significantly higher levels $(P<0.005-0.0005)$ of Snai1, Twist 1, Twist2, Tgfb1, and Vim than ALDH ${ }^{\text {low }}$ cells, with Twist2 showing the greatest fold-change (Fig. 5a). Although Snai2 and Fn1 tended to be higher in ALDH ${ }^{\text {high }}$ cells, neither was statistically significant in nine independent experiments. These data are consistent with the $\mathrm{BCS}_{\mathrm{L}} \mathrm{C}$ properties of $\mathrm{ALDH}^{\text {high }}$ cells. AHR hyper-activation with FICZ significantly $(P<0.05-0.0005)$ increased Snai1, Twist1, Twist2, and Vim in both ALDH ${ }^{\text {high }}$ and ALDH ${ }^{\text {low }}$ cells (Fig. 5b,c) and Tgfb1 was marginally increased in FICZ-treated ALDH ${ }^{\text {low }}$ cells (Fig. 5c).

As a functional readout of migration, the effects of AHR modulation on the ability of SUM149 cells to migrate in a 48 hour scratch-wound assay were determined. SUM149 cells were chosen for this experiment since, unlike Hs578T cells, ALDH ${ }^{\text {high }}$ SUM149 cells remained ALDHhigh in vitro for at least 96 hours, unless the AHR inhibitor, $\mathrm{CH} 223191$ was added (Additional file 3: Figure S3A). $\mathrm{ALDH}^{\text {low }}$, SUM149 cells tended to revert to ALDH ${ }^{\text {high }}$ phenotype but this reversion was inhibited by $\mathrm{CH} 223191$ treatment (Additional file 3: Figure S3B). Similar results describing the plasticity of stem-like cells have been previously reported [58].

As expected, vehicle-treated ALDH ${ }^{\text {high }}$ cells 'repaired' the wound significantly faster than vehicle-treated $\mathrm{ALDH}^{\text {low }}$ cells, as quantified by a decrease in exposed surface area (Fig. $6 ; P<0.05$ at 48 hours). Furthermore, wound repair with both subpopulations was significantly inhibited by $\mathrm{CH} 223191$ treatment (Fig. 6; $P<0.05-0.0005$ ). Similar data were obtained with unsorted Hs578T and SUM149 cells and with another AHR inhibitor, CB7993113 (not shown). No cell divisions were observed over this 48-hour period as assessed by CFSE staining and analysis by flow cytometry (not shown). In addition, both $0.5 \mu \mathrm{M}$ FICZ and $1 \mathrm{nM}$ TCDD significantly accelerated migration of unsorted, $\mathrm{ALDH}^{\text {low }}$ (not shown), and ALDH ${ }^{\text {high }}$ SUM149 subsets (Additional file 4: Figure S4). A significant increase 

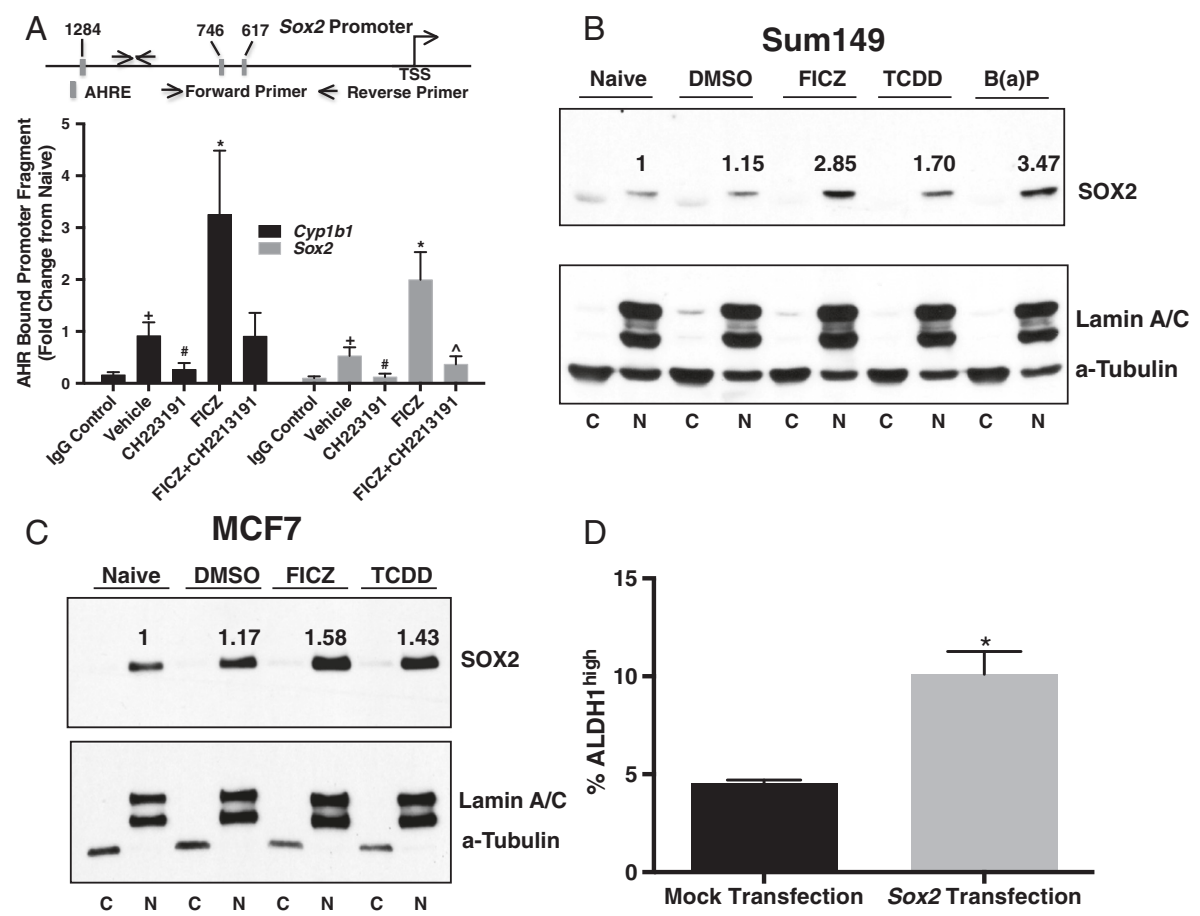

Fig. 4 Modulation of AHR activity affects AHR binding to Cyp 161 and Sox2 promoters and SOX2 protein production. (a) Hs578T cells were treated with vehicle, $10 \mu \mathrm{M}$ AHR inhibitor CH223191, $0.5 \mu \mathrm{M}$ FICZ, or $0.5 \mu \mathrm{M}$ FICZ + $10 \mu \mathrm{M}$ AHR inhibitor CH223191 for 48 hours and ChIP assays were performed with human AHR-specific antibody and Cyp1b1-or Sox2-specific promoters as described in the Materials and Methods. Data are presented as mean fold-change \pm standard error, IgG control $n=4$, vehicle $n=5, C H 223191 n=4$, FICZ $n=5$, FICZ $+C H 223191=4$. An asterisk indicates a significant increase relative to vehicle controls, ${ }^{*} P<0.05$. A pound sign indicates a significant decrease relative to vehicle controls, ${ }^{\#} P<0.05$. A cross indicates a significant increase relative to $\operatorname{lgG}$ controls, ${ }^{+} P<0.005$. A caret sign indicates a significant decrease relative to FICZ treatment, $\wedge P<0.05$. Relative positions of putative AHR response elements and amplified fragments are represented in the embedded map. (b) SUM149 or (c) MCF-7 cell cytoplasmic and nuclear protein extracts were probed for SOX2 protein expression following treatment with vehicle or AHR agonists: $0.5 \mu \mathrm{M}$ FICZ, $10 \mu \mathrm{M}$ B(a)P or $1 \mathrm{nM}$ TCDD. C = cytoplasmic extract, $\mathrm{N}$ = nuclear extract. The number above each band indicates fold-change from naïve after normalization to loading control, based on ImageJ densitometry analysis. (d) Hs578T cells were transfected with a CMV promoter-driven Sox2

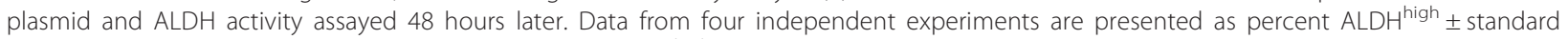
error. Asterisk indicates a significant increase in the \%ALDH ${ }^{\text {high }}$ cells, ${ }^{*} P<0.005$

in migration rate also was seen for ALDH ${ }^{\text {high }}$ cells following a 48-hour treatment with a lower TCDD dose $(0.2 \mathrm{nM}$, not shown).

\section{Generalization of the correlation between Ahr or Cyp1b1 and $\mathrm{BCS}_{\mathrm{L}} \mathrm{C}$ - and invasion/migration-associated genes}

The experiments described above confirm that AHR hyper-activation with FICZ induces both $\mathrm{BCS}_{\mathrm{L}} \mathrm{C}$ - and migration/invasion-associated genes in an AHR-dependent fashion in Hs578T cells. If these associations are generalizable to other breast cancer cell lines, then it would be predicted that $A h r$ expression and expression of Cyp1b1, as a marker for AHR activity, would correlate, in multiple breast cancer cell lines, with expression of the $\mathrm{BCS}_{\mathrm{L}} \mathrm{C}$ - and migration/invasion-associated gene sets identified in Hs578T cells. For such an analysis, we used microarray/RNA-seq data compiled by the Broad Institute on 79 primary human breast cancer cell lines, i.e. the Cancer Cell Line Encyclopedia (CCLE) [66]. Use of Cyp1b1 as a marker for AHR activity in this context is supported by (1) our findings [15], and those of others [67], demonstrating that baseline Cyp1b1 mRNA levels are maintained in part by 'constitutively active' AHR in human breast cancer cell lines, and (2) the observation that, of all breast cancer cell lines in the CCLE, the nearest neighbor to $A h r$ of $>20,000$ gene probes is Cyp1b1 $(P=0.0019$; this is not to say that there are no other factors regulating Cyp1b1 expression [67]). Gene set enrichment analyses (GSEA) were performed with the aim of testing whether the gene set listed in Table 1 is significantly and coordinately correlated with Ahr or Cyp1b1 expression. Indeed, Ahr expression was significantly correlated (false discovery rate $=0.025$ ) with the putative AHR target gene set shown in Table 1 (Additional file 5: Figure S5A). Similarly, there was a significant correlation between Cyp1b1 and the expression of the putative AHR target gene set $(F D R=0.021$; Additional file 5: Figure S5B). Interestingly, the 'outlier' with a negative correlation score for both the $A h r$ and Cyp1b1 analyses, was Msi1 

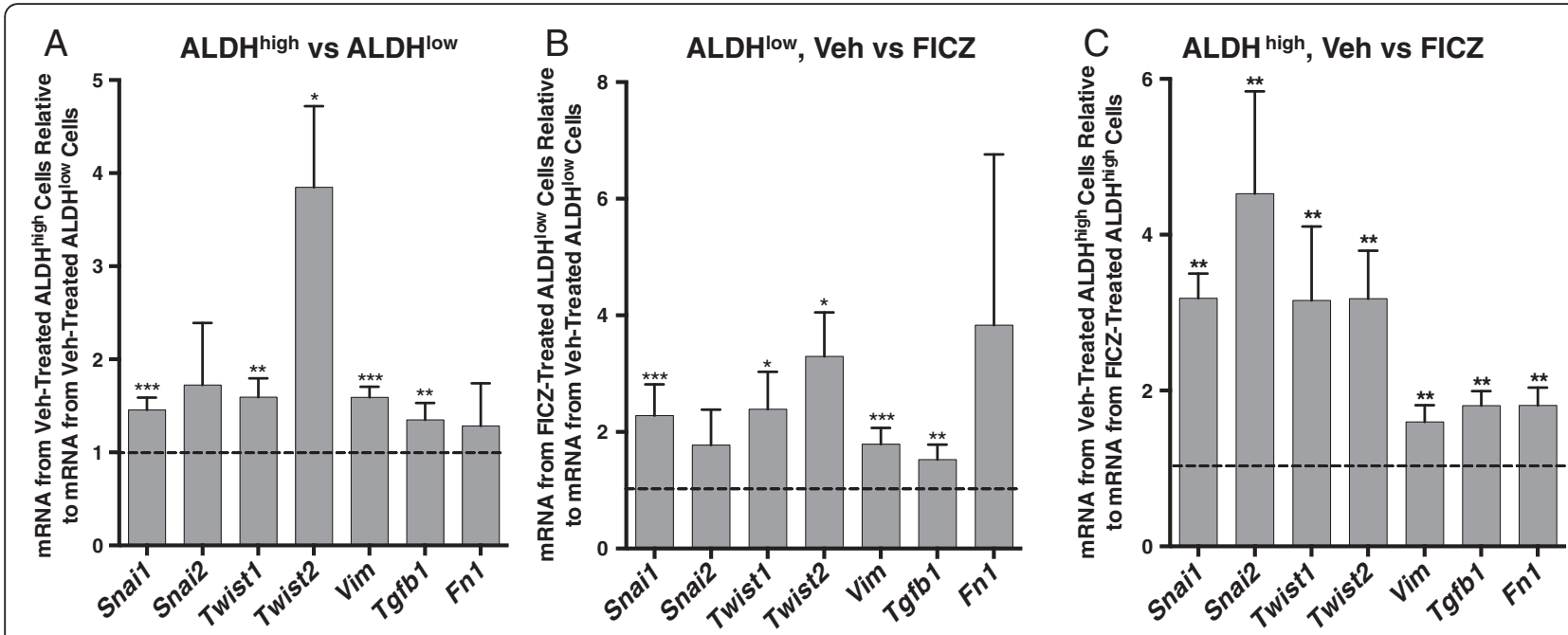

Fig. 5 AHR hyper-activation increases expression of migration and invasion-associated genes in Hs578T cells. Hs578T cells were treated with vehicle or $0.5 \mu \mathrm{M}$ FICZ for 48 hours, sorted into $\mathrm{ALDH}^{\text {high }}$ and ALDH ${ }^{\text {low }}$ cells, and then assayed by RT-qPCR for the relative levels of the seven migration and invasion-associated genes indicated. Gene expression was then normalized to Gapdh mRNA levels and fold-change from vehicle-treated ALDH ${ }^{\text {low }}$ or ALDH ${ }^{\text {high }}$ cells was calculated. Data from nine independent experiments are presented as mean fold-change \pm standard error. In all cases, statistical significance was determined with the Wilcoxon rank sum test to determine if the distributions of results, relative to 1 as the standard (represented by the dotted line on each graph), are different between the comparison groups. Asterisks indicate a significant increase in the mRNA fold-change, ${ }^{*} P<0.05$, ${ }^{* *} P<0.005$, ${ }^{* * *} P<0.0005$. (a) Migration- and invasion-associated gene expression levels were normalized to expression levels in vehicle-treated ALDH ${ }^{\text {low }}$ cells and the distribution of outcomes from vehicle-treated ALDH high versus vehicle-treated ALDH ${ }^{\text {low }}$ cells was compared. (b) Gene expression levels were normalized to expression levels in vehicle-treated $\mathrm{ALDH}^{\text {low }}$ cells and the distribution of outcomes from vehicle-treated ALDH ${ }^{\text {low }}$ versus FICZ-treated ALDH ${ }^{\text {low }}$ cells was compared. (c) Gene expression levels were normalized to expression levels in vehicle-treated ALDH ${ }^{\text {high }}$ cells and the distribution of outcomes from vehicle-treated $\mathrm{ALDH}^{\text {high }}$ versus FICZ-treated ALDH ${ }^{\text {high }}$ cells was compared

(Additional file 5: Figure S5A and S5B, red arrow), the one stem cell-associated gene we tested that did not increase following AHR hyper-activation (Fig. 3).

To generalize results to primary human cancers, a similar GSEA analysis was performed using transcriptomic data from 977 primary human breast cancers catalogued in the Cancer Genome Atlas (TCGA) database [68] and 995 primary human breast cancers in the Curtis database [69]. As shown for cell lines in the CCLE, there was a significant association $(\mathrm{FDR}=0.047)$ between $A h r$ expression and the gene set listed in Table 1 (Additional file 6: Figure S6A). A stronger association (FDR $=0.0001)$ was seen between Cyp1b1 expression and expression of the putative AHR target gene set (Additional file 6: Figure S6B). As with the CCLE database, Msi1 was not correlated with either $A h r$ or Cyp1b1 in the TCGA database (Red arrows, Additional file 6: Figure S6A, S6B). Similar data were obtained using the Curtis dataset (not shown). Collectively, data mined from three large breast cancer databases (CCLE, TCGA, and Curtis) show a significant and generalizable association between $A h r$ or AHR activity (Cyp1b1 expression) and cancer stem cell- and migration/invasion-associated gene sets, an outcome consistent with regulation of these genes by a constitutively active (i.e. endogenous AHR ligand-activated) AHR.

\section{Decreasing AHR activity decreases tumorsphere formation}

$\mathrm{BCS}_{\mathrm{L}} \mathrm{C}$ can form tumorspheres and produce progenitor cells in ultra-low adherence conditions over several passages [20,31, 70-73]. To determine if the AHR contributes to this functional readout of $\mathrm{BCS}_{\mathrm{L}} \mathrm{Cs}$, Hs578T cells were cultured in Mammocult media under ultra-low adherence conditions and AHR activity and expression were modulated with $\mathrm{CH} 223191$ or with a dox-inducible shAhr. Both the size and total number of tumorspheres were significantly reduced $(P<0.05-0.005)$ by $\mathrm{CH} 223191$ or a dox-induced shAhr in primary, secondary (Fig. 7a,b), tertiary, and quaternary (not shown) cultures. No effect on cell viability (trypan blue exclusion) was seen (the percent viability is indicated in the upper right corner of each image in Fig. 7a). Similar results were obtained with CB7993113 (not shown). These results suggest that the AHR regulates tumorsphere formation and the ability of $\mathrm{BCS}_{\mathrm{L}} \mathrm{Cs}$ to (asymmetrically) divide and/or differentiate into progenitor cells in low-adherence, selective conditions, and/or controls the ability of progenitor cells to divide.

\section{AHR controls expression of cancer stem cell-associated properties in an inflammatory breast cancer cell line} IBC is a particularly aggressive form of cancer characterized by a $\sim 50 \%$ survival rate at 2 years [74]. To determine if AHR control of stem cell characteristics 


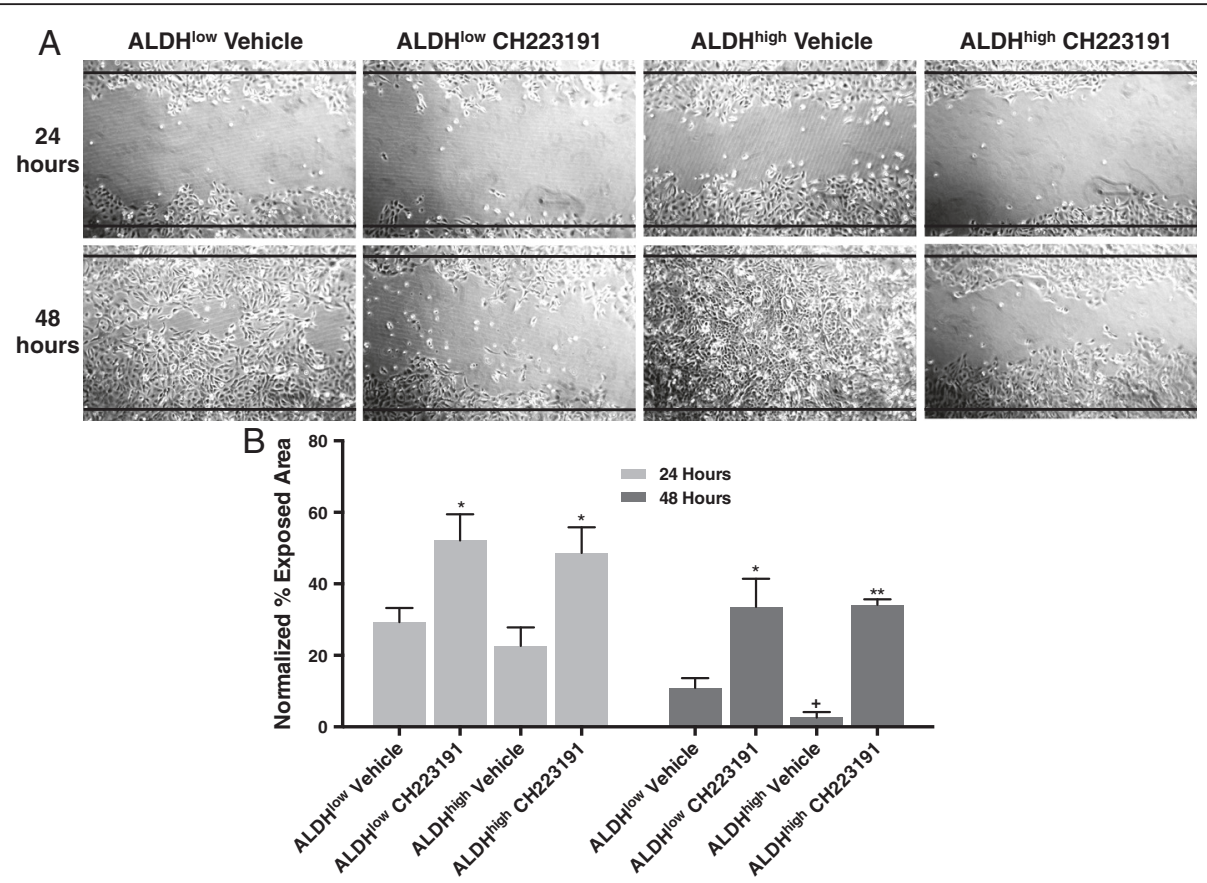

Fig. 6 AHR down-regulation decreases migration of SUM149 cells. (a) Presented are representative images of SUM149 cell migration at 24 and 48 hours after cells were sorted into $\mathrm{ALDH}^{\text {high }}$ and $\mathrm{ALDH}^{\text {low }}$ populations, cultured to confluence, scratched, and treated with vehicle or $10 \mu \mathrm{M}$ CH223191. Data are representative of three independent experiments. Black lines indicate the borders of the original scratch. (b) SUM149 cells were treated as in (a) and percent exposed area was quantified. Data from three experiments were normalized to results obtained with naïve cells and presented as mean percent exposed area \pm standard error. Asterisks indicate a significant increase in exposed area, ${ }^{*} P<0.05,{ }^{* *} P<0.0005$. A cross indicates a significant decrease in exposed area, ${ }^{+} P<0.05$

is generalizable to this cancer subtype, SUM149 cells, derived from an IBC, were studied for expression of $A h r$ and Cyp1b1 in ALDH ${ }^{\text {high }}$ and ALDH ${ }^{\text {low }}$ subpopulations, for the contribution of the AHR to ALDH1 activity, and for the ability to form tumorspheres. As shown for TNBC Hs578T cells, ALDH ${ }^{\text {high }}$ SUM149 cells expressed significantly higher $A h r$ and Cyp $1 b 1$ levels than $\mathrm{ALDH}^{\text {low }}$ cells $(P<0.05-0.005$; Fig. 8a). CH223191 or Ahr-specific shRNA significantly decreased AHR activity or expression greater than $60 \%$ $\left(P<0.01-0.0001\right.$; Fig. 8 b), the percentage of ALDH ${ }^{\text {high }}$ cells by over $80 \%(P<0.05-0.0005$; Fig. $8 \mathrm{c}, \mathrm{d})$, and overall ALDH1 activity in the entire population (not shown). Conversely, FICZ, $\beta-\mathrm{NF}$, TCDD, and DMBA significantly increased the percentage of $\mathrm{ALDH}^{\text {high }}$ cells $(P<0.01-$ 0.005; Fig. 8c,d) and $\mathrm{CH} 223191$ treatment in tandem significantly reduced this increase $(P<0.05-0.01$; Fig. $8 \mathrm{c}, \mathrm{d})$. Finally, fewer and smaller tumorspheres were formed following $\mathrm{CH} 223191$ treatment $(P<0.05-0.01$; Fig. 8e,f). No changes in cell viability were detected (the percent viability is indicated in the upper right corner of each image in Fig. 8e). These data parallel those found with Hs578T cells (Fig. 7) and suggest that AHR control of these stem cell properties is generalizable to other $\mathrm{ER}^{-}$breast cancer subtypes.

\section{Decreasing AHR activity decreases chemoresistance, a hallmark of $B C S_{L} C s$}

Chemoresistance is another widely studied functional $\mathrm{BCS}_{\mathrm{L}} \mathrm{C}$ marker $[21,22,53,72,73,75,76]$. To determine if the AHR influences chemoresistance, ALDH ${ }^{\text {high }}$ and $\mathrm{ALDH}^{\mathrm{low}} \mathrm{Hs} 578 \mathrm{~T}$ cells were treated with titrated doses of adriamycin or paclitaxel, chemotherapeutics with distinct mechanisms of action, with or without $\mathrm{CH} 223191$. Cell viability was assayed 24 hours later. As expected of $\mathrm{BCS}_{\mathrm{L}} \mathrm{Cs}, \mathrm{ALDH}{ }^{\text {high }}$ cells were more resistant to the chemotherapeutics than $\mathrm{ALDH}^{\text {low }}$ cells (see half maximal effective concentrations $\left(\mathrm{EC}_{50}\right)$ in Table 2). $\mathrm{CH} 223191$ had no effect on viability (not shown). However, CH223191 significantly $(P<0.05-0.005)$ increased sensitivity to both adriamycin and paclitaxel in both ALDH ${ }^{\text {low }}$ and $\mathrm{ALDH}^{\text {high }}$ cells (Fig. 9). The $\mathrm{EC}_{50}$ of adriamycintreated ALDH ${ }^{\text {high }}$ cells $\left(\mathrm{EC}_{50}=1.99 \mu \mathrm{M}\right)$ was three times greater than that of adriamycin $+\mathrm{CH} 223191$-treated cells $\left(\mathrm{EC}_{50}=0.60 \mu \mathrm{M}\right.$; Fig. 9b; Table 2). These results are consistent with previous reports demonstrating AHR control of chemotherapeutic-induced breast cancer cell apoptosis [77]. Furthermore, they indicate that migration/invasion-associated genes, and functional markers of $\mathrm{BCS}_{\mathrm{L}} \mathrm{Cs}$ (tumorsphere formation, rapid migration, chemoresistance) are influenced by the AHR. 


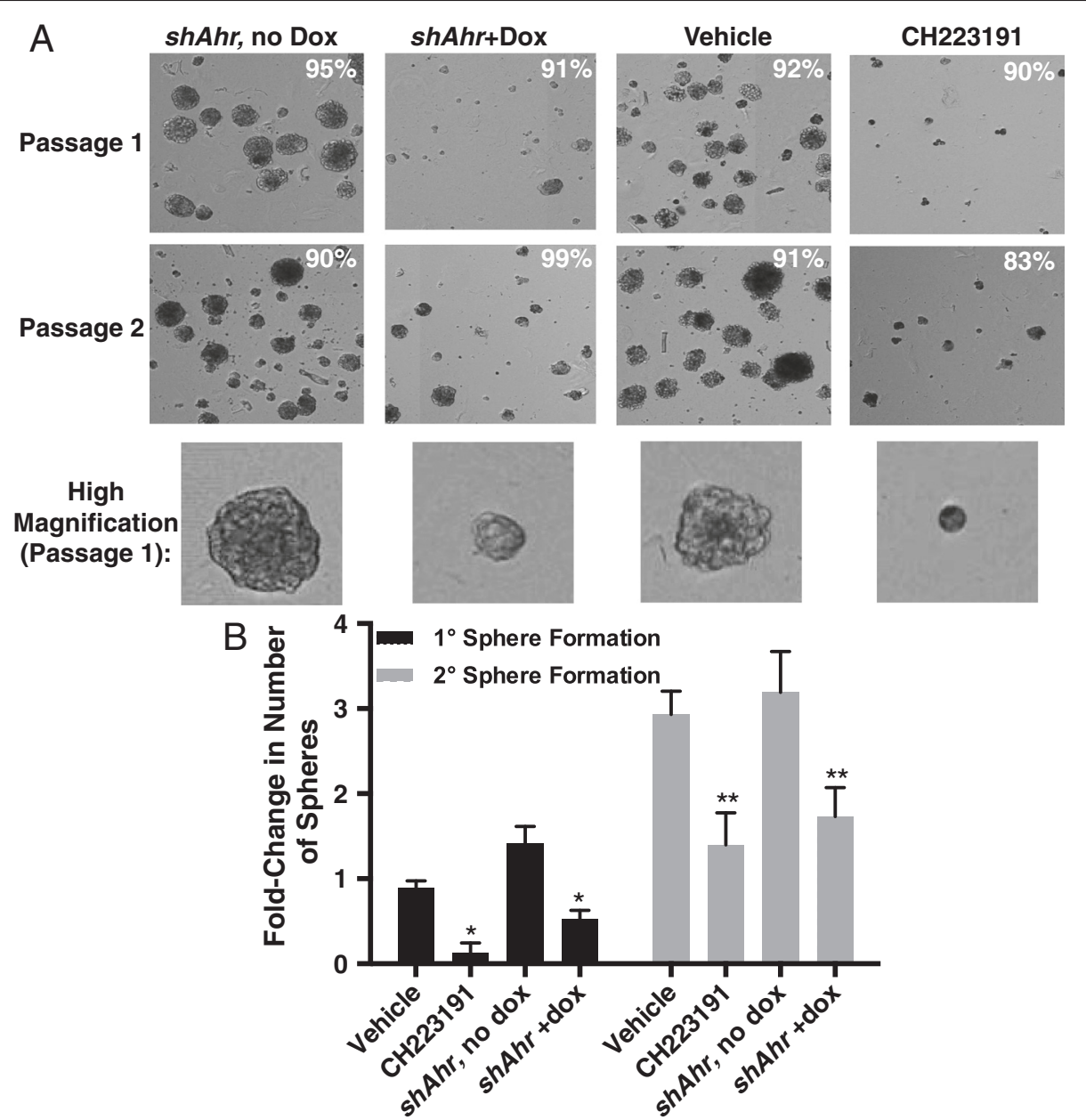

Fig. 7 AHR down-regulation decreases Hs578T tumorsphere formation. (a) Dox-inducible shAhr-transduced Hs578T ('shAhr') or wildtype Hs578T cells were left untreated or treated for 48 hours with vehicle, doxycycline, or $10 \mu \mathrm{M} \mathrm{CH} 223191$ as indicated and cultured in Mammocult media under ultra-low adherence conditions. Representative images of primary (day 8) and secondary (day 16, following passage at day 8) tumorspheres are presented. The percentage of viable cells is included on each image. Vehicle and $\mathrm{CH} 223191$ treatment groups are representative of six independent experiments. shAHR, no dox and shAHR + dox treatment groups are representative of five independent experiments. (b) Hs578T cells were treated as in (a) and tumorsphere formation was quantified. Data from six experiments were normalized to results obtained with naïve cells and presented as mean fold-changes from naive \pm standard error. Asterisks indicate a significant decrease in the percentage of tumorspheres, ${ }^{*} P<0.05,{ }^{*} P<0.005$

shAhr-mediated AHR knockdown decreases expansion of tumors initiated with ALDH ${ }^{\text {high }}$ and ALDH ${ }^{\text {low }}$ SUM149 cells Cancer stem cells tend to generate tumors more efficiently in vivo than non-cancer stem cells $[18-20,31,72]$. To determine if AHR, which increases expression of stem cellassociated properties in vitro, influences tumor cell fate in vivo, SUM149 cells, stably transduced with a doxinducible shAhr (Fig. 8), were sorted and 3,000 ALDH ${ }^{\text {high }}$ and $\mathrm{ALDH}^{\text {low }}$ cells were injected into the right and left mammary fat pads, respectively, of female NOD/SCID mice. Half of the mice were given doxycycline-containing water to induce the $s h A h r$. ALDH ${ }^{\text {high }}$ cells generated palpable tumors more rapidly and these tumors grew faster than $\mathrm{ALDH}^{\text {low }}$ cells (growth rates of 0.26 vs. $0.19 \mathrm{~mm} /$ day, $P<0.0001$; Fig. 10a). Furthermore, dox-induced shAhr significantly reduced growth rates from 0.26 to 0.18 and from 0.19 to $0.11 \mathrm{~mm} /$ day in $\mathrm{ALDH}^{\text {high }}$ and $\mathrm{ALDH}^{\text {low }}$ cells, respectively $(P<0.0005$; Fig. 10b,c). Consistent with in vitro experiments, Ahr, Cyp1b1, Aldh1a1, and Sox2 mRNA levels were reduced in tumors from doxycyclinetreated mice (Fig. 11).

Although ALDH1 activity and Aldh1 expression have been identified as a valid marker for $\mathrm{BCS}_{\mathrm{L}} \mathrm{Cs}[19,23,50$, 53, 78] and despite ALDH ${ }^{\text {high }}$ cells having formed tumors sooner than $\mathrm{ALDH}^{\text {low }}$ cells in the experiment described above, we wanted to confirm that ALDH ${ }^{\text {high }}$ cells, in our hands, exhibit a hallmark property of cancer stem cells in vivo, i.e. efficient formation of tumors following xenografting. Therefore, SUM149 cells, stably transduced with a different doxycycline-inducible $s h A H R$, were sorted into $\mathrm{ALDH}^{\text {high }}$ and $\mathrm{ALDH}^{\text {low }}$ subpopulations and xenografted at titered numbers $(10,000,5,000,2,500$ cells $)$ into the 


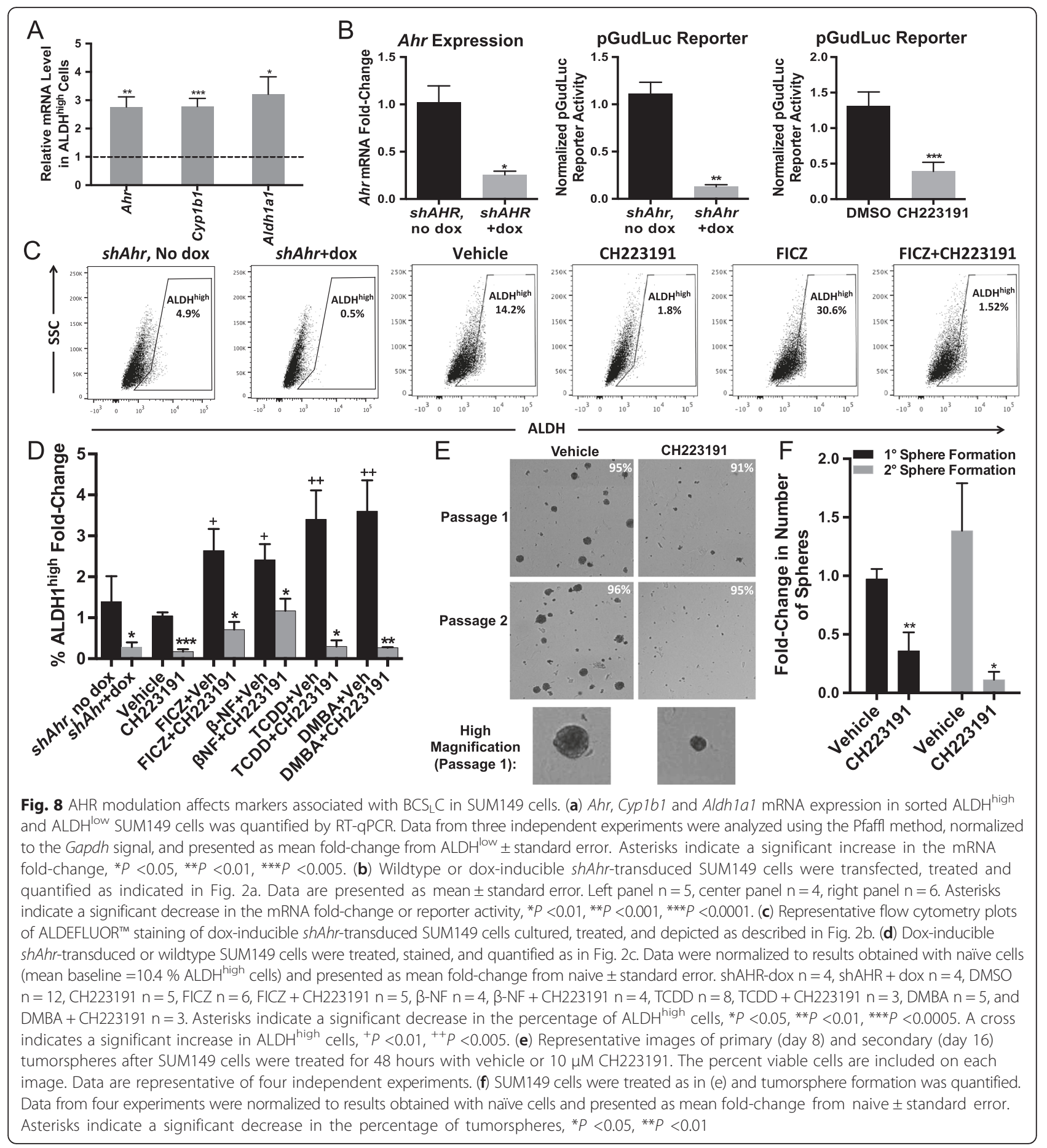

mammary fat pads of female NOD/SCID recipients (six mice/group). Tumor volume was then tracked over a 69-day period. As predicted of tumors derived from cells with cancer stem-like properties, tumors generated from $\mathrm{ALDH}^{\text {high }}$ cells were detected sooner than tumors generated from ALDH ${ }^{\text {low }}$ cells at each respective cell number, thereby demonstrating a consistently higher efficiency of tumor initiation (Figs. 12 and 13). Tumors grew faster after xenograft of 10,000 ALDH $^{\text {high }}$ as compared with $\mathrm{ALDH}^{\text {low }}$ cells. Furthermore, induction of shAhr with doxycycline significantly delayed tumor formation and subsequent growth of tumors generated from both $\mathrm{ALDH}^{\text {high }}$ cells and $\mathrm{ALDH}^{\text {low }}$ cells regardless of cell number transferred to recipients. These data strongly support the use of ALDH activity as a marker for breast cancer cells with cancer stem cell-like properties and the conclusion 
Table 2 Half maximal effective concentrations ( $E C_{50}$ ) of two chemotherapeutics in the presence or absence of an AHR inhibitor

\begin{tabular}{llc}
\hline Cell population & Drug treatment & Chemotherapeutic $\mathrm{EC}_{50}(\mu \mathrm{M})$ \\
\hline $\mathrm{ALDH}^{\text {low }}$ & Paclitaxel & 0.81 \\
$\mathrm{ALDH}^{\text {low }}$ & Paclitaxel $+\mathrm{CH}$ & 0.56 \\
$\mathrm{ALDH}^{\text {high }}$ & Paclitaxel & 1.21 \\
$\mathrm{ALDH}^{\text {high }}$ & Paclitaxel $+\mathrm{CH}$ & 0.76 \\
$\mathrm{ALDH}^{\text {low }}$ & Adriamycin & 0.55 \\
$\mathrm{ALDH}^{\text {low }}$ & Adriamycin $+\mathrm{CH}$ & 0.20 \\
$\mathrm{ALDH}^{\text {high }}$ & Adriamycin & 1.99 \\
ALDH $^{\text {high }}$ & Adriamycin $+\mathrm{CH}$ & 0.60 \\
\hline
\end{tabular}

$\mathrm{EC}_{50}$ values were calculated from the data presented in Fig. 9

that AHR influences the efficiency with which all cells along a continuum of low to high ALDH expression can initiate tumors.

\section{Discussion}

Accumulating data suggest that the AHR plays an important role in breast cancer, in general, and in progression to end-stage invasion and migration in particular. For example, the AHR is hyper-expressed and transcriptionally active in most TNBC and IBC cell lines, and its expression is associated with tumor invasion $[10,13,15,79]$. The data presented here strongly suggest that the AHR drives tumorigenesis in part through induction or maintenance of cells with cancer stem cell-like properties.

The involvement of the AHR in $\mathrm{BCS}_{\mathrm{L}} \mathrm{C}$ biology is suggested by its emerging role in normal tissue-specific stem cell development. For example, the AHR, presumably activated by endogenous ligand(s), helps maintain hematopoietic stem cell self-renewal and block differentiation [36, 37, 80], and drives bipotential blood stem cell differentiation [39]. AHR repression in embryonic stem cells likely maintains pluripotency, and the AHR controls embryonic stem cell differentiation into cardiomyocytes [38]. Data presented here extend these studies by demonstrating that the AHR is involved in the phenotype (ALDH1 activity and Aldh1a1 expression), genomics (up-regulation of stem cell- and migration/invasionassociated genes), and function (migration, chemoresistance, tumorigenicity) of $\mathrm{BCS}_{\mathrm{L}} \mathrm{Cs}$.

Elevated $\mathrm{ALDH}$ expression identifies $\mathrm{BCS}_{\mathrm{L}} \mathrm{Cs}$ and is associated with increased expression of chemoresistance proteins, increased tumor cell invasion, higher tumor grade, and poor survival in breast cancer patients $[19,21,28,32,53]$. Indeed, in our hands, ALDH ${ }^{\text {high }}$ cells exhibited increased chemoresistance (Fig. 9), elevated expression of stem cell- and migration/invasion-associated genes (Figs. 3 and 5), faster migration (Fig. 6), higher tumor-initiating capacity and increased tumor growth rates in vivo (Figs. 10, 12 and 13). AHR control of chemoresistance is particularly interesting given important

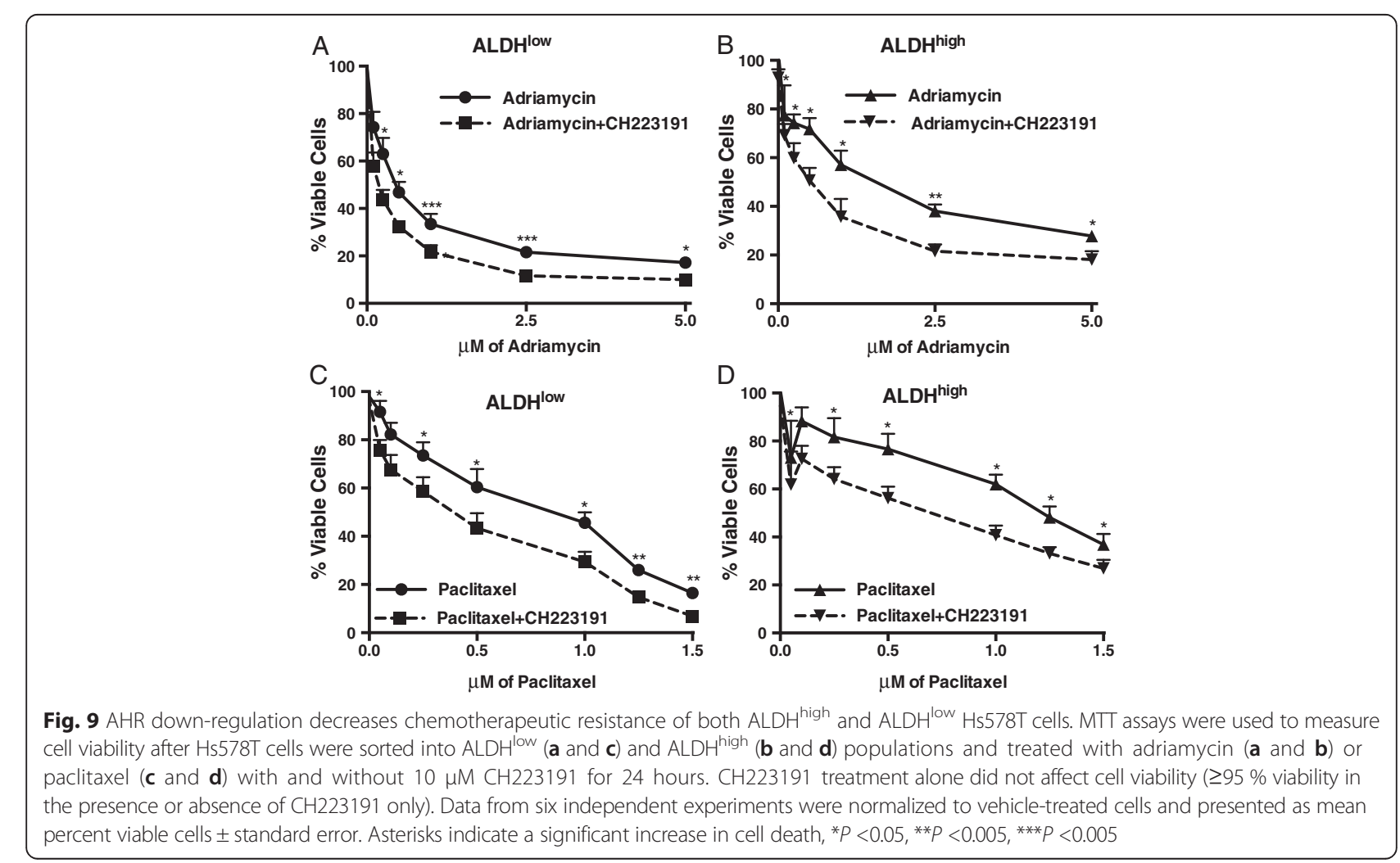




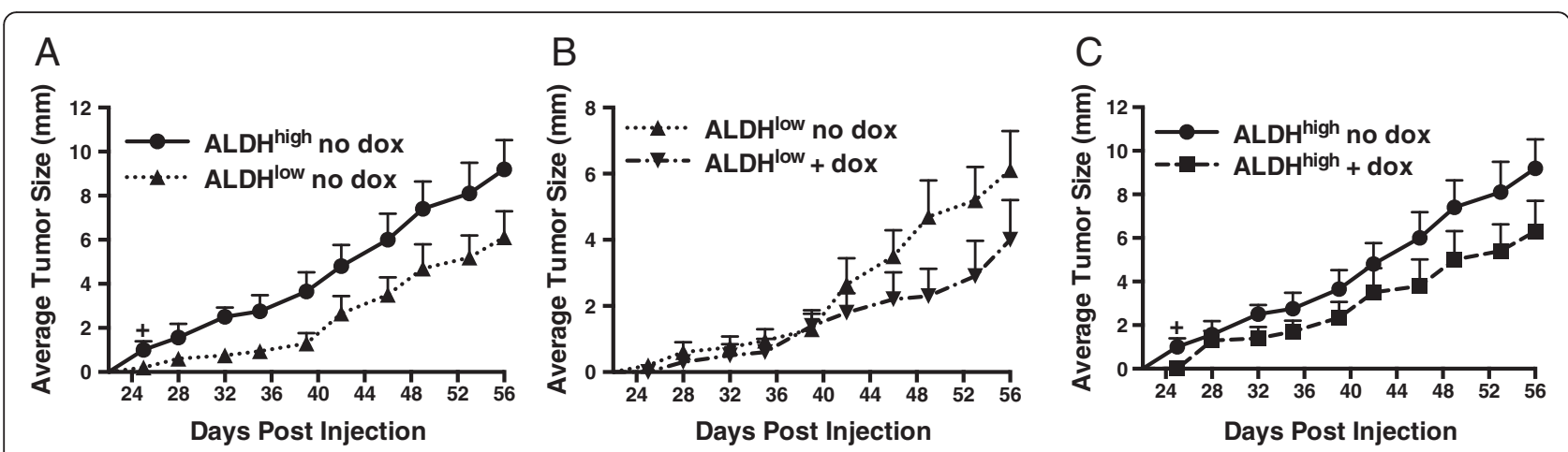

Fig. 10 AHR down-regulation decreases tumor formation in xenograft mice. (a) Doxycycline-inducible shAhr-expressing SUM149 cells were sorted for $\mathrm{ALDH}^{\text {high }}$ or $\mathrm{ALDH}^{\text {low }}$ activity and 3,000 cells were grafted into the mammary fat pads of NOD/SCID mice (10 mice/group). Tumor volumes were measured over the next 56 days. Data are presented as mean tumor volume \pm standard error; $P<0.0001$. The average rate of tumor growth of tumors initiated with $A L D H^{\text {high }}$ cells $\left(0.26 \mathrm{~mm} /\right.$ day) was significantly different than the rate of growth of tumors initiated with ALDH ${ }^{\text {low }}$ cells $\left(0.19 \mathrm{~mm} /\right.$ day),$P<0.0005$. A cross indicates a significant increase in average tumor size beginning at day $25,{ }^{+} P<0.01$. (b) Doxycycline-inducible shAhr-expressing SUM149 cells were sorted for low ALDH expression and 3,000 cells were grafted into the mammary fat pads of NOD/SCID mice. Mice then were given water $+5 \%$ sucrose or water with doxycycline $+5 \%$ sucrose and tumor volumes were quantified over the next 56 day period. The average rate of tumor growth of $\mathrm{ALDH}^{\text {low }}$ cells in control mice $\left(0.19 \mathrm{~mm} /\right.$ day) was significantly different than that of $A L D H^{\text {low }}$ cells in dox-treated mice $(0.11 \mathrm{~mm} /$ day), $P<0.0005$. (c) Doxycycline-inducible shAhr-expressing SUM149 cells were sorted for high ALDH expression and 3,000 cells were grafted into the mammary fat pads of NOD/SCID mice. Mice were then given water $+5 \%$ sucrose or water with doxycycline + $5 \%$ sucrose. Tumor volumes were measured over the next 56 day period. The average rate of tumor growth in water-treated control mice $(0.26 \mathrm{~mm} /$ day $)$ was significantly different than the rate of tumor growth in dox-treated mice $(0.18 \mathrm{~mm} /$ day $), P<0.0005$. A cross indicates a significant increase in tumor size beginning at day $25,{ }^{+} p<0.01$

recent studies demonstrating that TCDD decreases and AHR inhibition increases apoptosis induced by UV light or chemotherapeutics in six breast cancer cell lines [77]. AHR-mediated chemoresistance takes on even greater significance given recent studies showing that chemoresistance may be a more meaningful marker of metastatic behavior than markers of epithelial-to-mesenchymal transition [25]. These data support the hypothesis that AHR inhibitors may represent effective, targeted therapeutics when used in combination with conventional chemotherapeutics. Collectively, these data strongly support the conclusion that $\mathrm{ALDH}^{\text {high }}$ cells are at least breast cancer stem-like cells if not bona fide breast cancer stem cells.

We previously demonstrated that constitutively active AHR in breast cancer lines preferentially drives Cyp $1 b 1$ expression while an exogenous ligand, e.g. DMBA, tends to induce greater fold-increases in Cyp1a1 than Cyp $1 b 1$ [15]. Interestingly, higher relative levels of Cyp1b1 were noted in ALDH ${ }^{\text {high }}$ cells, as compared with ALDH ${ }^{\text {low }}$ cells (Fig. 3a), suggesting the possibility that a higher level of AHR activity, as represented by baseline Cyp $1 b 1$ levels, characterizes ALDH ${ }^{\text {high }}$-stem like cells.

AHR hyper-activation with FICZ increased expression of Aldh1a1 and stem cell-associated genes demonstrating a causal relationship between AHR activity and expression of these genes (Fig. 3b,c). This gene set has been implicated in generating both normal tissue stem cells and $\mathrm{BCS}_{\mathrm{L}}$ Cs. Notch1 and Notch 2 are critical to symmetric and asymmetric cell division, stem cell differentiation in embryonic and adult stem cells [26, 81], and are potential therapeutic targets $[76,82]$. Bmi1 is required for the maintenance of somatic stem cells through repression of cellular senescence and cell death [83], and is involved in the control of $\mathrm{BCS}_{\mathrm{L}} \mathrm{C}$ growth, chemoresistance, and tumorsphere formation [84]. Stella is involved in maintenance of gene-specific DNA methylation in the early embryo, and is a marker for some $\mathrm{BCS}_{\mathrm{L}} \mathrm{C}$ types [85]. Sox2, Oct4 and Nanog are traditional embryonic stem cell markers used to reprogram cells to a pluripotent state, and are expressed at elevated levels in $\mathrm{BCS}_{\mathrm{L}} \mathrm{Cs}[27,30,85,86]$. Sox 2 is up-regulated in TNBCs and has been implicated in tumorsphere formation and control of tumor initiation [27, 62, 63]. Therefore, the finding that the AHR directly interacts with the Sox2 promoter (Fig. 4a) strongly suggests that the AHR is at the apex of an important signaling pathway that controls cancer progression by increasing phenotypic and functional expression of cancer stem cell-associated markers within the tumor cell population.

Our data also suggest that the AHR plays a key role in regulating $\mathrm{BCS}_{\mathrm{L}} \mathrm{C}$ migration. Snail, Slug, Twist1, Twist2, $T g f b 1$, and Fibronectin (Fn1), which contribute to cell invasion and cell migration $[28,87,88]$, are all up-regulated in FICZ-treated ALDH ${ }^{\text {high }}$ cells (Fig. 5c). As would be predicted from these results, AHR inhibition slows (Fig. 6) and AHR hyper-activation accelerates (Additional file 4: Figure S4) cell migration in the scratch-wound assay.

Importantly, these findings on AHR-regulated genes appear generalizable since strong correlations were seen between $A h r$ or Cyp1b1 and the stem cell- and 

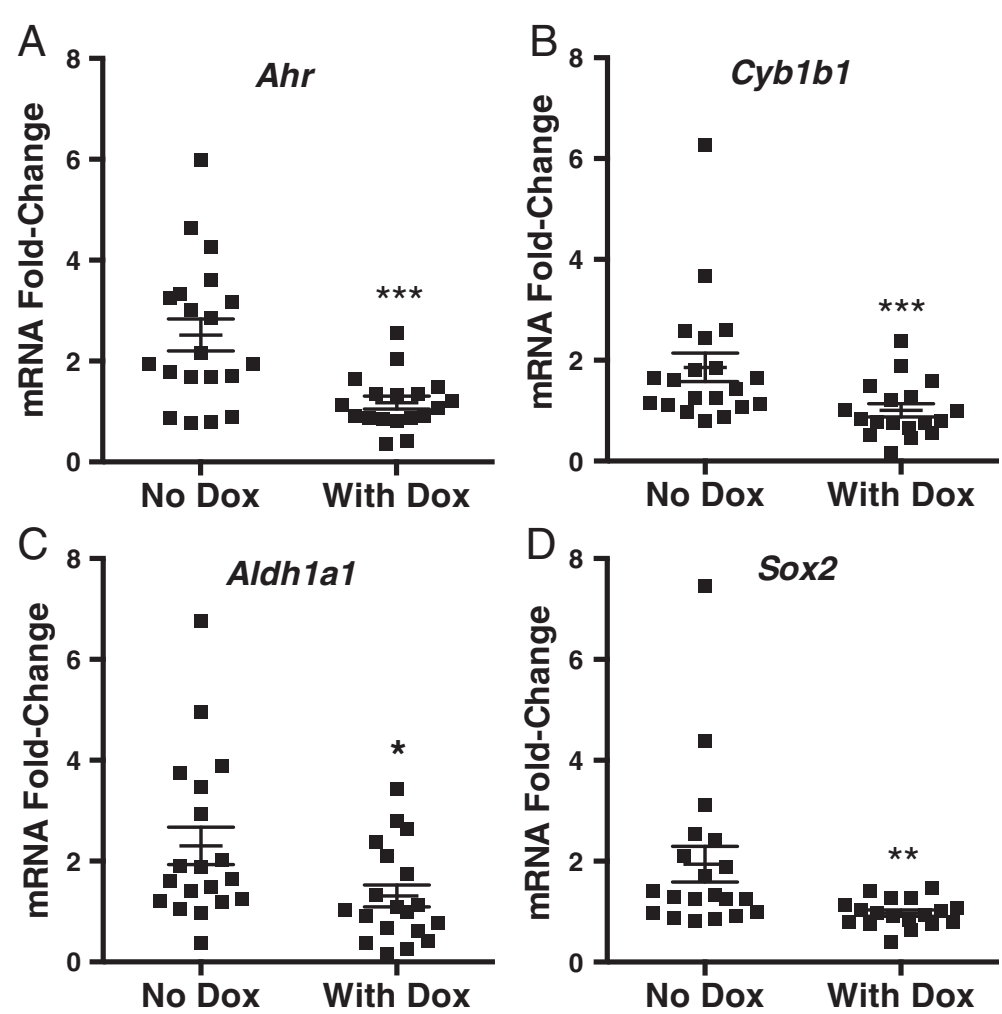

Fig. 11 AHR down-regulation decreases expression of Ahr, Aldh1a1, Cyp1b1, and Sox2 in xenografted mouse tumors. Twenty NOD/SCID mice were injected with 3,000 dox-inducible shAhr-transduced ALDH high or ALDH ${ }^{\text {low }}$ SUM149 cells as described in Fig. 10. Half of the mice were provided with water containing $2 \mathrm{mg} / \mathrm{mL}$ doxycycline to induce the shAhr and tumors were harvested after 42-72 days when they reached $15 \mathrm{~mm}$ in total size (control mice $n=20$, mice with doxycycline treatment $n=19$ ). (a) Ahr, (b) Cyp1b1, (c) Aldhial, and (d) Sox2 mRNA expression levels were assayed by RT-qPCR. Since the AHR controls expression of Cyp1b1, Aldh1a1, and Sox2 in both ALDH ${ }^{\text {high }}$ and ALDH ${ }^{\text {low }}$ cells (e.g. Fig. 3), data generated with tumors from $\mathrm{ALDH}^{\text {high }}$ and $\mathrm{ALDH}^{\text {low }}$ tumors were pooled for statistical purposes. Data are presented as fold-change relative to the average $C T$ value from control mice, i.e. no dox, grafted with $\mathrm{ALDH}^{\text {low }}$ cells \pm standard error. Asterisks indicate a significant decrease in the mRNA fold-change, ${ }^{*} P<0.05,{ }^{*} P<0.01,{ }^{* *} P<0.005$

migration/invasion-associated gene sets in databases of 79 human breast cancer cell lines characterized in the CCLE and over 1850 primary human breast cancers catalogued in the TCGA and Curtis databases (Additional files 5 and 6: Figure S5 and S6). Furthermore, these results suggest the possibility that the AHR contributes to cell invasion and migration through upregulation of stem cell- and invasion/migration-associated genes.

Consistent up-regulation of CYP1B1 in breast cancers [89] suggests that this enzyme plays an important role in cancer, potentially by influencing cell migration [90]. It is, therefore, formally possible that at least some of the effects observed here reflect AHR ligand binding to CYP1B1. While this possibility cannot be ruled out, particularly for ligands such as FICZ, which are metabolized by CYP1B1 [91], it seems unlikely as a general rule since TCDD, which is not metabolized by CYP1B1 and does not bind CYP1B1 (data not shown), generates the same outcomes (increase in stem cell-associated genes, cell migration) as the other ligands.

AHR inhibition or knockdown in either Hs578T or SUM149 cells significantly reduced the number and size of tumorspheres formed in low adherence conditions over several generations (Figs. 7 and 8e,f). The formation of these colonies is generally considered to be a function of asymmetric $\mathrm{BCS}_{\mathrm{L}} \mathrm{C}$ division and production of progenitor cells which constitute the majority of the cells in the spheres $[31,70,72]$. Therefore, it is possible that the AHR controls the asymmetric differentiation of $\mathrm{BCS}_{\mathrm{L}} \mathrm{C}$ and/or the growth of their progenitors.

Furthermore, AHR knockdown with either of two shAhr constructs significantly slowed the initiation and outgrowth of both ALDH ${ }^{\text {low }}$ and ALDH ${ }^{\text {high }}$ cell-derived tumors (Figs. 10b, c, 12b, c, 13). This decrease in tumor outgrowth was accompanied by a decrease in Cyp1b1, Aldh1a1, and Sox2 expression (Fig. 11), further linking AHR activity to expression of these genes. 


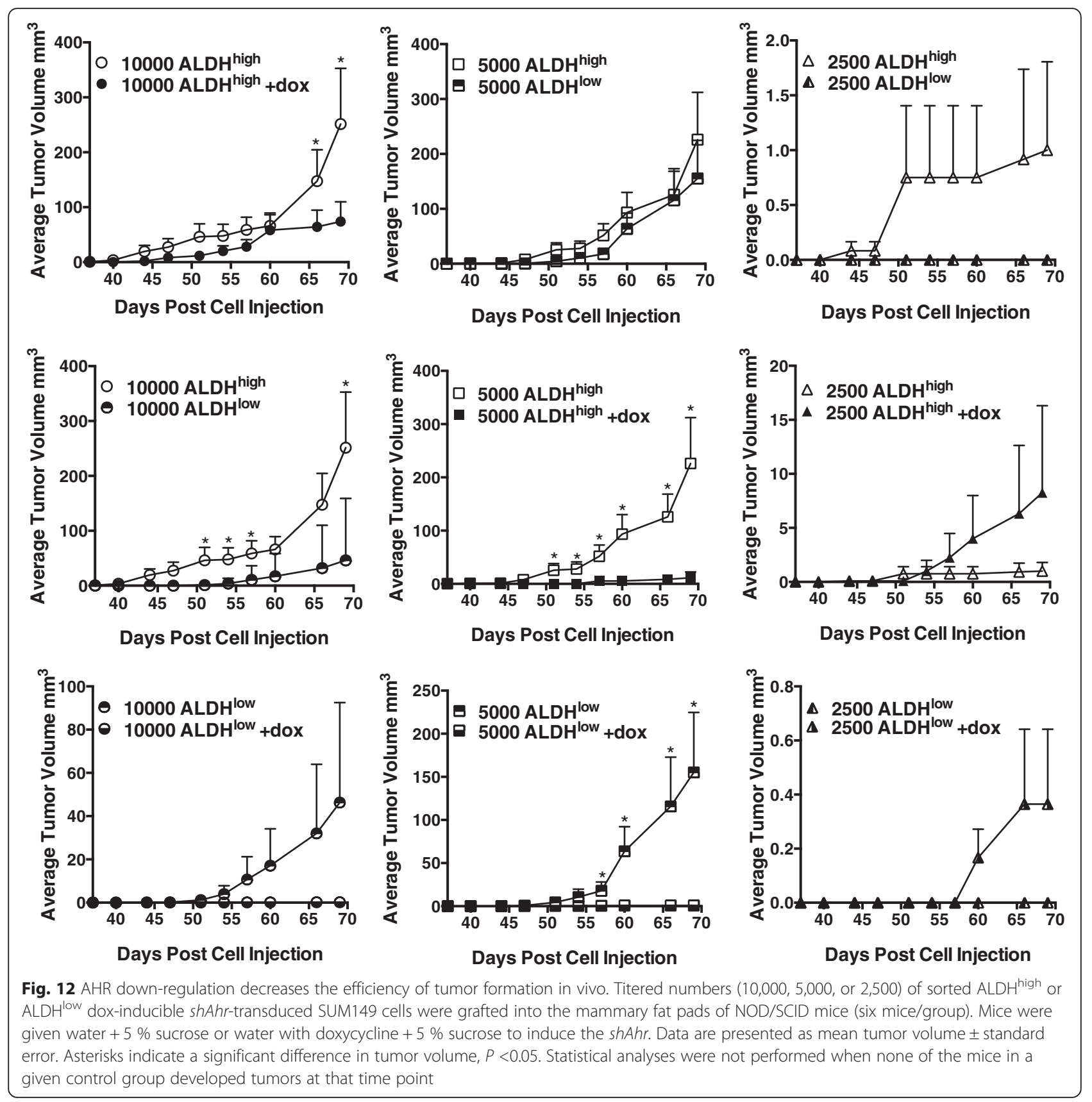

Results presented here are reminiscent of several studies demonstrating that baseline (endogenous ligand-induced) AHR activity in immortalized cells favors tumor growth or aggressive behavior [12-14, 92-97]. Paradoxically, several studies indicate that exogenous AHR ligands can reduce tumor growth or invasion [41, 92, 96, 97]. As elegantly described in a recent review [98], these seemingly contradictory results may, in part, reflect context- or tumor stage-specific differences. For example, AHR agonists may inhibit growth in $\mathrm{ER}^{+}$breast cancers in part through AHR-mediated down-regulation of ER expression or activity [41]. However, in similar cell types [47, 99, 100], similar AHR agonist- and antagonistmediated outcomes could be due to more subtle effects on AHR activation or signaling. For instance, it has been postulated that, while endogenous AHR ligands drive signaling towards, for example, increased invasion, exogenous AHR ligands 'divert' [10] or 'disrupt' [92] the response towards signaling pathways which oppose tumor invasion, e.g. differentiation [47]. Furthermore, exogenous ligands, e.g. Tranilast, that decrease invasion $[99,100]$, may act as partial agonists that compete with endogenous ligands for AHR binding but which are weaker activators of AHR transcriptional activity, thereby reducing baseline AHR 

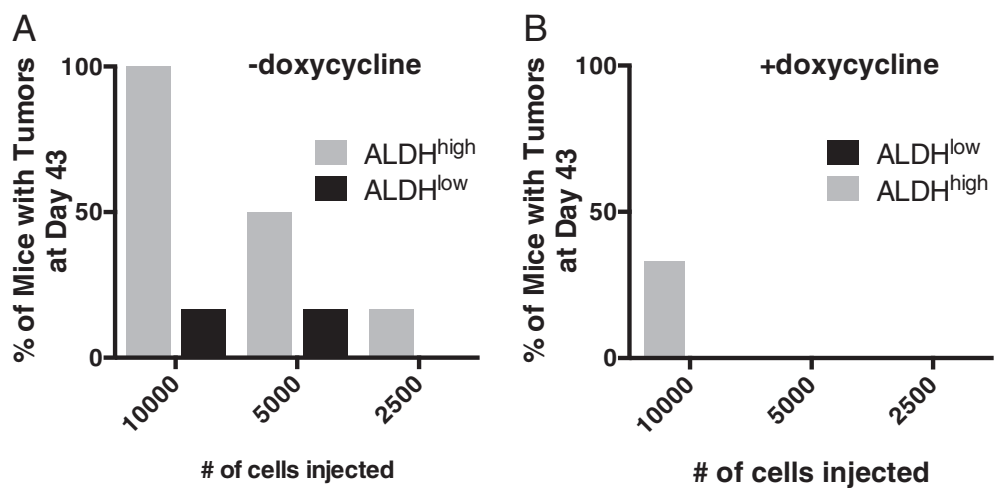

Fig. 13 Percent of mice bearing tumors 43 days after receiving orthotopic xenografts of 10,000, 5,000, or 2,500 ALDH ${ }^{\text {high }}$ or ALDH $^{\text {low }}$ SUM149 cells. The percentage of mice with palpable tumors at day 43 of the experiment presented in Fig. 12 was determined as a measure of tumor initiation efficiency. Mice were given either $(\mathbf{a})$ water $+5 \%$ sucrose $(n=20)$ or $(\mathbf{b})$ water with doxycycline $+5 \%$ sucrose to induce expression of $\operatorname{shAHR}(\mathrm{n}=20)$

signaling [101]. Finally, outcomes may be ligand-, cell subset-, or dose-specific. Thus, high affinity AHR ligands, such as TCDD, induce stem cell characteristics including ALDH expression and accelerated migration, particularly at low doses (e.g. 0.2-1 nM; Additional file 4: Figure S4, and data not shown), while higher doses $(10 \mathrm{nM})$ may reduce invasiveness of the majority non- $\mathrm{BCS}_{\mathrm{L}} \mathrm{C}$ population [47].

Finally, a limited number of previous studies have addressed the role of the AHR in breast cancer stem cell generation $[96,97,99,102]$. While these studies all point towards a role for the AHR in cancer stem-like cell generation, there is as yet no clear consensus on how this occurs or even on whether the AHR favors or inhibits $\mathrm{BCS}_{\mathrm{L}} \mathrm{C}$ production/function. For example, Zhao et al. [96] showed that AHR activation with $\beta-\mathrm{NF}$ or $3-\mathrm{MC}$ or over-expression of a PasB mutant AHR decreased tumorsphere formation; in our hands, only 3-MC reduced secondary tumorsphere formation in SUM149 and MCF-7 cells (data not shown). In what may seem like a contradiction, Zhao et al. [97] later published that MCF-7 mammosphere formation was suppressed by AHR inhibition with CH223191 as well as by siRNAmediated AHR knockdown in MDA-MB-453 cells. In Dubrovska et al. [102], AHR inhibitors reduced the percentage of ALDH ${ }^{\text {high }}$ MCF-7 cells in tamoxifen-resistant MCF-7 (as shown in our studies with triple negative Hs578T and SUM149 cells) but produced the opposite effect in wildtype MCF-7 cells. At least some of these differences can be attributed to the different subtypes of breast cancer cells (i.e. $\mathrm{ER}^{+}$, Luminal A-type or Her-2 over-expressing MCF-7 cells versus ER ${ }^{-}$, basal-like, triple negative Hs578T and SUM149 cells). In any case, further experimentation is required to determine how the AHR influences 'stem-ness' in breast cancer cells.

\section{Conclusions}

Studies presented here indicate that the AHR influences, in TNBC and IBC cells, critical markers associated with 'stem-ness'. The ability of several exogenous AHR ligands, including TCDD and DMBA to up-regulate phenotypic, genomic, and/or functional markers of $\mathrm{BCS}_{\mathrm{L}} \mathrm{Cs}$ strongly suggests the potential for ubiquitous environmental AHR ligands to accelerate progression to lethal, invasive cancers. Furthermore, the demonstration that AHR inhibition significantly reduces expression of these phenotypic and functional cancer stem cell markers encourages the testing of AHR inhibitors, for example, to significantly increase the sensitivity of $\mathrm{BCS}_{\mathrm{L}} \mathrm{Cs}$ to conventional chemotherapeutics. In general, these results suggest that non-toxic AHR modulators may represent important therapeutics for otherwise refractory TNBC and IBC, and potentially for brain and other cancers in which the AHR appears to play a role.

\section{Methods}

\section{Chemicals}

DMSO, $\beta$-NF, DMBA, TCDD, paclitaxel, doxorubicin, and doxycycline were obtained from Sigma-Aldrich (St. Louis, MO). FICZ, CH223191, and CB7993113 were provided by Dr. M. Pollastri (Northeastern University).

\section{Cell line acquisition, cell culture, and media}

Hs578T and MCF-10F cells were purchased from ATCC and cultured according to ATCC recommendations (ATCC, Manassas, VA). SUM149 cells were a generous gift from Dr. Stephen Ethier (Wayne State University, Detroit, MI). SUM149 cells were maintained in F-12 K Medium (Mediatech, Herndon, VA) containing $5 \%$ FBS (Sigma-Aldrich), $0.5 \mu \mathrm{g} / \mathrm{mL}$ hydrocortisone (Sigma-Aldrich), $2 \mathrm{mM}$ L-glutamine (Mediatech), $100 \mathrm{IU}$ 
penicillin/100 $\mu \mathrm{g} / \mathrm{mL}$ streptomycin (Mediatech), $10 \mu \mathrm{g} /$ $\mathrm{mL}$ insulin (Sigma-Aldrich), and $5 \mu \mathrm{g} / \mathrm{mL}$ Plasmocin (Invivogen, San Diego, CA).

\section{Inducible, stable $A$ hr-specific shRNA cells}

Doxycycline (dox)-inducible TurboRFP-shAhr TRIPZ lentiviral vectors (Open Biosystems, Huntsville, AL) were used to make viral transduction particles. Hs578T and SUM149 cells were transduced at optimal MOIs of 25 and 50, respectively, in medium containing hexadimethyrine bromide (8 $\mu \mathrm{M} \mathrm{g} / \mathrm{mL}$ polybrene; Sigma-Aldrich). Transduced cells were maintained in $1.5 \mu \mathrm{g} / \mathrm{mL}$ puromycin (Invitrogen, Grand Island, NY). RFP expression was maximal 48 hours after dox treatment $(1.5 \mu \mathrm{g} / \mathrm{mL})$ of transduced cells. For in vivo experiments, two different inducible shAHR plasmids were constructed and used to generate two independent doxycycline-inducible shAHR-expressing SUM149 lines.

\section{ALDEFLUOR ${ }^{\text {TM }}$ staining}

Cells were dosed with $0.5 \mu \mathrm{M}$ FICZ, $1 \mu \mathrm{M} \beta$-NF, $10 \mu \mathrm{M}$ CH223191, $10 \mu \mathrm{M}$ CB7993113, $1 \mathrm{nM}$ TCDD, $1 \mu \mathrm{M}$ DMBA, $1.5 \mu \mathrm{g} / \mathrm{mL}$ dox, vehicle (0.1 \% DMSO), and/or left untreated every 24 hours. After 48 hours, ALDEFLUOR ${ }^{\mathrm{mm}}$ assays were performed according to the manufacturer's instructions (Stem Cell Technologies, Vancouver, Canada). Briefly, cells $\left(10^{6}\right.$ cells $\left./ \mathrm{mL}\right)$ were treated with $5 \mu \mathrm{L} / \mathrm{mL}$ ALDEFLUOR $^{\mathrm{TM}}$ substrate in $1 \mathrm{~mL}$ of ALDEFLUOR ${ }^{\mathrm{TM}}$ buffer. Negative controls were treated with both ALDEFLUOR $^{\text {TM }}$ substrate and $50 \mathrm{mmol} / \mathrm{L}$ diethylaminobenzaldehyde (DEAB), an ALDH-specific inhibitor. Samples were incubated for 35 minutes at $37^{\circ} \mathrm{C}$ in the dark. After $35 \mathrm{mi}$ nutes, cells were centrifuged, the supernatant was removed and the remaining pellet was suspended in ice-cold ALDEFLUOR $^{\mathrm{TM}}$ buffer and kept on ice. Before samples were read on the flow cytometer, propidium iodine was added $(1.5 \mu \mathrm{g} / \mathrm{mL})$ to quantify viability (propidium iodine was not used on TurboRFP-shAhr transduced cells due to overlapping emissions). Cells were immediately assayed with an LSRII flow cytometer (Becton Dickinson Biosciences, San Jose, CA) using DEAB controls as baselines to gate ALDHhigh and $\mathrm{ALDH}^{\text {low }}$ cell populations. ALDH ${ }^{\text {high }}$ and $\mathrm{ALDH}^{\text {low }}$ cells were sorted on a MoFlo Legacy (Beckman Coulter, Indianapolis, IN). All flow cytometry data was analyzed using Flowjo software (Ashland, OR) according to Stem Cell Technologies' manufacturer instructions. Briefly, DEABtreated control samples were used to make $\mathrm{ALDH}^{\text {high }}$ and $\mathrm{ALDH}^{\text {low }}$ gates as pictured in Fig. 1. The percent of cells that fell into each gate was then quantified as $\mathrm{ALDH}^{\text {high }}$ or $\mathrm{ALDH}^{\text {low }}$ subsets.

\section{Western blotting}

Cells were lysed and protein extracted using NE-PER Nuclear and Cytoplasmic Extraction Reagents (ThermoFisher Scientific, Grand Island, NY), according to manufacturer instructions. Protein concentration was then quantified via a Bradford protein assay. Equal amounts of protein $(40 \mu \mathrm{g})$ were subjected to $10 \%$ SDS-PAGE and then transferred to a nitrocellulose membrane. Non-specific binding sites were blocked with blocking buffer containing Tris-buffered saline and $0.1 \%$ Tween- 20 with $5 \%$ nonfat milk powder for 1 hour at room temperature, and the blot was incubated with specific antibody in blocking buffer (SOX2, Lamin $\mathrm{A} / \mathrm{C}$ and $\alpha$-Tubulin antibody in 1:1000 dilution, respectively) at $4{ }^{\circ} \mathrm{C}$ overnight. After washing, the blot was incubated with an appropriate secondary antibody conjugated with horseradish peroxidase for 1 hour at room temperature. After washing, the detection was performed using the enhanced chemiluminescence system. The antibody of SOX2 was purchased from Cell Signaling Technology (Danvers, MA; Cat \#: 2748), Lamin A/C from Cell Signaling Technology (Cat \#: 2032), and $\alpha$-Tubulin from EMD Millipore (Billerica, MA; Cat \#: CP06). Image J (National Institutes of Health, Bethesda, MD) was used to perform densitometry analysis. Fold-change from naïve is presented following normalization to loading control (Lamin A/C for nuclear extract and $\alpha$-tubulin for cytoplasmic extract).

\section{Tumorsphere formation}

Cells were treated as above. After 48 hours, cells were harvested, dosed, and $3 \times 10^{3}$ cells plated in complete MammoCult Medium (STEMCELL Technologies) containing $0.5 \mu \mathrm{M}$ hydrocortisone, $2 \mathrm{mM}$ L-glutamine, $100 \mathrm{IU}$ penicillin $/ 100 \mu \mathrm{M} \mathrm{g} / \mathrm{mL}$ streptomycin, and $1 \%$ methylcellulose (Sigma Aldrich) in ultra-low adherent 24-well plates (Corning Inc.). Colonies were quantified with a Celigo S Imaging Cytometer (Brooks Automation, Chelmsford, MA) after 8 days. For secondary sphere formation, tumorspheres were mechanically and enzymatically dissociated into a single cell suspension, re-dosed, re-plated, and imaged as above.

\section{RT-qPCR}

mRNA was extracted using RNeasy ${ }^{\circ}$ Plus Mini Kit (Qiagen, Valencia, CA) and cDNA prepared using the GoScript $^{\text {ti }}$ Reverse Transcription System (Promega, Madison, WI) with a 1:1 mixture of random and Oligo $(\mathrm{dT})_{15}$ primers according to manufacturer's instructions. All RT-qPCR reactions were performed using the GoTaq ${ }^{\circ}$ RT-qPCR Master Mix System (Promega). Validated primers were purchased from Qiagen Inc. (Valencia, CA): human Cyp1b1 - QT00209496, Cyp1a1 - QT00012341, Twist1 - QT00011956, Snai1 - QT00010010, Snai2 QT00044128, VIM - QT00095795, Twist2 QT02454004, FN1 - QT00038024, Notch1 QT01005109, Notch2 - QT00072212, Aldh1a1 QT00013286, Aldh1a3 - QT00077588, Pou5f1 QT00210840, Sox - QT00237601, Nanog - QT01844808, 
Dppa3 - QT01667197, Msi1 - QT00025389, Human Bmi1 - QT00052654, Tgfb1 - QT00000728, Ahr QT02422938, and Gapdh - QT01192646. RT-qPCR reactions were performed using a 7900HT Fast Real-Time PCR instrument (Applied Biosystems, Carlsbad, CA), with hot-start activation at $95{ }^{\circ} \mathrm{C}$ for $2 \mathrm{~min}, 40$ cycles of denaturation $\left(95{ }^{\circ} \mathrm{C}\right.$ for $\left.15 \mathrm{sec}\right)$, and annealing/extension $\left(55{ }^{\circ} \mathrm{C}\right.$ for $\left.60 \mathrm{sec}\right)$. Relative gene expression was determined using the Pfaffl method [103] and the threshold value for Gapdh mRNA was used for normalization.

\section{Chromatin immunoprecipitation (ChIP) assay}

ChIP studies were performed using an AHR-specific antibody (ab2769; Abcam, Cambridge, MA) and the ChIP kit (ab500; Abcam) according to the manufacturer's protocol. Cells were fixed and sonicated to produce fragments averaging $500 \mathrm{bp}$. Following immunoprecipitation with AHR-specific antibody or normal mouse IgG (Santa Cruz Biotechnology, Dallas, TX), DNA was purified and amplified using the following primers: $C y p 1 b 1$ primer: 5'-GTTTGGCGCTGGGTTAC-3' and 5'-AGGTCGGAG CTGACTCTCT-3' [104], Sox2 primer: 5'CTGTGAG AAGGGCGTGAGAG-3' and 5'- AAACAGCCAGTGCA GGAGTT-3'. The relative DNA amount was calculated using the $\Delta \Delta \mathrm{Ct}$ method. AHR and IgG control pull-down signal were normalized to input signal.

\section{Transient transfection}

Hs578T or SUM149 cells were co-transfected with the $p$ Gudluc reporter plasmid $(0.5 \mu \mathrm{g})$ (generously provided by Dr. M. Denison, UC, Davis), and $C M V$ green $(0.1 \mu \mathrm{g}$; for normalization) using TransIT-2020 transfection reagent (Mirus, Madison, WI). The transfection medium was replaced after 24 hours. The cells were left untreated or dosed with vehicle (DMSO, $0.1 \%$ final concentration), $0.5 \mu \mathrm{M}$ FICZ or $\mathrm{CH} 223191$ $(10 \mu \mathrm{M})$, and harvested after 24 hours in Glo Lysis Buffer (Promega, San Luis Obispo, CA). Luciferase activity was determined with the Bright-Glo Luciferase System according to the manufacturer's instructions (Promega). Luminescence and fluorescence were determined using a Synergy2 multifunction plate reader (Bio-Tek, Winooski, VT).

\section{Scratch-wound assay}

$\mathrm{ALDH}^{\text {high }}$ and $\mathrm{ALDH}^{\text {low }}$ cells were sorted and grown to confluence in 12-well plates. A p200 pipet tip was used to make an ' $\mathrm{X}$ ' in each well and non-adherent cells were removed with PBS washes. Media was added and cells treated with vehicle, $10 \mu \mathrm{M}$ CH223191, $1 \mathrm{nM}$ TCDD, or $0.5 \mu \mathrm{M}$ FICZ. Media was changed and cells were redosed daily. TScratch software (Tobias Gebäck and Martin Schulz, ETH Zürich) was used to quantify the closure of the scratch over time.

\section{Mouse model}

Eight-week old, female non-obese diabetic-severe combined immunodeficiency (NOD/SCID) mice were purchased from Jackson Laboratory (Bar Harbor, ME). To determine if the AHR influences this parameter of $\mathrm{BCS}_{\mathrm{L}} \mathrm{Cs}$, two separate in vivo experiments were performed. For both experiments, SUM149 cells that were stably transduced with either of two dox-inducible shAHR were sorted into $\mathrm{ALDH}^{\text {high }}$ and $\mathrm{ALDH}^{\text {low }}$ cell populations. For the first in vivo experiment, $3000 \mathrm{ALDH}^{\text {high }}$ and $\mathrm{ALDH}^{\text {low }}$ cells in $100 \mu \mathrm{L}$ of 50:50 Matrigel/DMEM were injected into the right and left mammary fat pads, respectively, of female NOD/SCID mice. For the second in vivo experiment, titered numbers $(2,500,5,000$, or 10,000$)$ of $\mathrm{ALDH}^{\text {high }}$ and $\mathrm{ALDH}^{\text {low }}$ cells in $100 \mu \mathrm{L}$ of 50:50 Matrigel/DMEM were injected into the right and left mammary fat pads, respectively, of female NOD/SCID mice. For both experiments, control mice drank water with $5 \%$ sucrose, while the treated mice were provided with water containing $5 \%$ sucrose and $2 \mathrm{mg} / \mathrm{mL}$ doxycycline to induce the shAHR. Tumor growth was quantified using Vernier calipers and animals were sacrificed when the total tumor burden reached $15 \mathrm{~mm}$. No metastases were noted at this time. Necropsies were performed to resect the tumors from both sides. RNA was isolated from each of the primary tumors for gene expression analyses for the first in vivo experiment. Animals were housed at the Association for Assessment and Accreditation of Laboratory Animal Care certified Boston University Medical Laboratory Animal Science Center and used in accordance with the NIH Guide for the Care and Use of Laboratory Animals. A Boston University Medical Campus Institutional Animal Care and Use Committee approved protocol and National Institutes of Health Guide for the Care and Use of laboratory Animals were followed.

\section{Immunofluorescence}

Hs578T and SUM149 cells were grown overnight on glass cover slips. Upon harvest, cells were washed with cold PBS, fixed with $4 \%$ fresh paraformaldehyde for 10 minutes, permeabilized in $0.5 \%$ Triton X-100 for 10 minutes, and blocked with $2 \%$ BSA overnight. Cells were incubated with anti-AHR antibody H-211 (Santa Cruz Biotechnology, Dallas, TX) for 2 hours, washed in PBS and incubated with Alexa Fluor 594 conjugated anti-rabbit IgG (Molecular Probes, Eugene, OR) for 60 minutes. Cover slips were washed and mounted on slides with ProLong ${ }^{\oplus}$ Gold Antifade Reagent (Life Technologies, Carlsbad, CA). Photomicrography was performed with a Nikon Deconvolution Wide-Field Epifluorescence Microscope using NIS Elements software. No background fluorescence was detectable in samples treated with the secondary antibody alone. 


\section{Immunohistochemistry}

Immunohistochemistry was performed on slides of paraffin-embedded, $5 \mu \mathrm{m}$-thick sections of breast invasive ductal carcinoma in a tissue microarray (US Biomax, Inc., Rockvilla, MD) by standard protocol on an intelliPATH Automated Slide Staining System from Biocare Medical (Concord, CA). Briefly, the slides were heated for $15 \mathrm{mi}-$ nutes at $60{ }^{\circ} \mathrm{C}$ followed by deparaffinization starting with xylene and rehydrated through graded alcohols to distilled water. Antigen-retrieval was then performed using Diva Decloaker (Biocare Medical) reagent at $100{ }^{\circ} \mathrm{C}$ for $35 \mathrm{mi}-$ nutes, and then at $85{ }^{\circ} \mathrm{C}$ for 10 minutes. Slides were incubated with Biocare Medical Peroxidase 1 solution for 10 minutes at room temperature, washed with TBST, blocked with Biocare Medical Background Sniper for 30 minutes and washed. Primary AHR-specific antibody (clone H-211, 1:50 dilution, Santa Cruz Biotechnology) was diluted in Biocare Medical Da Vinci Green Diluent and incubated for 2 hours at room temperature followed by washing in TBST. Incubation in Biocare Medical Mach 4 Universal HRP Polymer was then performed for 30 minutes followed by washing in TBST. DAB was diluted in DAB substrate buffer and applied to slides for 5 minutes followed by washing in deionized- $\mathrm{H}_{2} \mathrm{O}$. A light hematoxylin stain was applied, the slides were dehydrated, air dried, and mounted, using EcoMount and a coverslip. Microphotography was performed with an Olympus Upright Microscope using QCapture software. No background stain was detectable in the absence of AHR-specific antibody.

\section{Statistical analyses}

Statistical analyses were performed with Prism (GraphPad Software, La Jolla, CA) or StatPlus (Alexandria, VA) unless otherwise noted. Data are presented as mean \pm standard error where applicable. One-way analysis of variants (ANOVAs; simple) were used to determine significance. For experiments measuring relative fold-changes in gene expression (determined using the Pfaffl method [103] with Gapdh mRNA used for normalization), statistical analyses were performed using SAS v9.3. For comparisons of fold-change in vehicle-treated ALDH ${ }^{\text {high }}$ versus vehicletreated $\mathrm{ALDH}^{\text {low }}$, and FICZ-treated $\mathrm{ALDH}^{\text {low }}$ versus vehicle-treated ALDH ${ }^{\text {low }}$ cells, Gapdh-normalized expression levels were normalized to expression levels in vehicletreated $\mathrm{ALDH}^{\text {low }}$ cells. For comparisons of fold-change with FICZ-treated ALDH ${ }^{\text {high }}$ versus vehicle-treated $\mathrm{ALDH}^{\text {high }}$ cells, Gapdh-normalized expression levels were normalized to expression levels in vehicle-treated ALDHhigh cells. Statistical significance was determined with the Wilcoxon rank sum test. Statistical analyses of the mouse model compared the average rate of change over time between groups using a random effects model with a random intercept for each mouse. Day 22 was used as the starting (baseline) value to calculate the rate of change. All mouse analyses were performed using SAS v9.3 using a 0.05 level of significance.

\section{Availability of supporting data}

The data sets supporting the results of this article are included within the article and its additional files (Additional file 7, excel document). For further information, please contact the corresponding author.

\section{Additional files}

Additional file 1: Additional Figure S1. Nuclear AHR staining in triple negative breast cancer cell lines and primary breast cancers. (A) AHR immunofluorescence staining in SUM149 (left) and Hs578T (right) triple negative breast cancer cell lines are shown (Top: bright field in black and white; Bottom: Alexafluor fluorescence in black and white). (B) AHRspecific staining in tissue from two representative human breast cancers from a total of 50 samples is shown (Top: normal breast control, Middle: Her $2^{+}$, invasive ductal carcinoma; Bottom: $\mathrm{ER}^{-} / \mathrm{PR}^{-} / \mathrm{Her} 2^{-}$invasive ductal carcinoma). (PDF $10468 \mathrm{~kb}$ )

Additional file 2: Additional Figure S2. AHR modulation alters ALDH activity in ER', immortalized MCF-10 F epithelial cells. (A) Representative flow cytometry dot plots of ALDEFLUOR ${ }^{\mathrm{TM}}$ staining of MCF10F cells treated for 48 hours with vehicle, $10 \mu \mathrm{M} \mathrm{CH} 223191$, or $0.5 \mu \mathrm{M}$ FICZ. Regions representing $\mathrm{ALDH}^{\text {high }}$ cells were drawn based on the signal generated in the presence of DEAB. (B) MCF-10 F cells were treated as in (A) and assayed for the percentage of $A L D H^{\text {high }}$ cells. Data from four experiments were normalized to results obtained with naive cells (mean baseline $=0.2 \%$ $\mathrm{ALDH}^{\text {high }}$ cells) and presented as mean fold-change from naive \pm standard error. Asterisks indicate a significant decrease in the percentage of ALDH ${ }^{\text {high }}$ cells, ${ }^{*} P<0.05$, ${ }^{*} P<0.005$. A cross indicates a significant increase in $A L D H{ }^{\text {high }}$ cells, ${ }^{+} P<0.05$. (PDF $97 \mathrm{~kb}$ )

Additional file 3: Additional Figure S3. Limited plasticity of SUM149 with regard to ALDH expression. SUM149 cells were sorted into $\mathrm{ALDH}^{\text {high }}$ and $\mathrm{ALDH}^{\mathrm{low}}$ populations and treated for 96 hours with vehicle or $1 \mu \mathrm{M} \mathrm{CH} 223191$. Every 24 hours, cells were assayed for the percent of (A) ALDH high and (B) $\mathrm{ALDH}^{\text {low }}$ cells to determine how quickly cells revert to the baseline ALDH $\mathrm{H}^{\text {high }}$ and $\mathrm{ALDH}^{\text {low }}$ levels. Data are presented as the means from 3 (72 and 96 hours) or 4 (0, 24 and 48 hours) experiments \pm standard errors. (PDF $48 \mathrm{~kb}$ )

Additional file 4: Additional Figure S4. AHR agonists accelerate migration of SUM149 cells. (A) Representative images of cell migration at 24 and 48 hours after SUM149 cells were sorted into the ALDH ${ }^{\text {high }}$ population, cultured to confluence, scratched, and treated with vehicle, $0.5 \mathrm{MM}$ FICZ or $1 \mathrm{nM}$ TCDD. Data are representative of five independent experiments. Black lines indicate the borders of the original scratch. (B) ALDH ${ }^{\text {high }}$ SUM149 cells were treated as in (A) and the percent exposed area was quantified at 24 and 48 hours. Data from five experiments were normalized to results obtained with naive cells and presented as the mean percent exposed area \pm standard error. Asterisks indicate a significant decrease in exposed area, ${ }^{*} P<0.05$, ${ }^{* *} P<0.01$. (PDF $6744 \mathrm{~kb}$ )

Additional file 5: Additional Figure S5. Ahr and Cyp $1 b 1$ expression correlate with expression of stem cell- and migration/invasionassociated genes in the CCLE database. The gene set enrichment analysis (GSEA) tool (http://www.broad.mit.edu/gsea) was used to rank genes from the cancer cell line encyclopedia (CCLE) dataset [66] based on the correlation of their expression profiles with (A) Ahr and (B) Cyp 161 expression. Considering stem cell- and migration/invasion-associated genes present in the CCLE microarray data, their position in the ranked list (represented with vertical black lines in the panels) incremented the enrichment score statistic (ES, plotted in green). A significant positive correlation between Ahr or Cyp 161 and the gene set was demonstrated by GSEA ( $P=0.025$ and 0.021 , respectively), with Msi1 showing the lowest correlation value in both analyses. (PDF $99 \mathrm{~kb}$ ) 
Additional file 6: Additional Figure S6. Ahr and Cyplb1 expression correlate with expression of stem cell- and migration/invasion-associated genes in the TCGA database. Expression of genes from the cancer genome atlas (TCGA) dataset [68] were ranked based on the correlation of their expression profiles with Ahr (A) and Cyplb1 (B) expression. The enrichment score (in green) was computed by considering the position of the stem cell- and migration/invasion-associated genes in the ranked list obtained from the TCGA RNA-Seq data. A significant positive correlation between expression of the putative AHR target genes and Ahr or Cyp 161 expression ( $P=0.047, P=0.0001$, respectively) was demonstrated. The ranking of Msil demonstrated a low correlation with both Ahr and Cyp1b1 expression. (PDF $100 \mathrm{~kb}$ )

Additional file 7: The data sets supporting the results of each of the figures in this article are included within this excel document. For further information, please contact the corresponding author. (XLSX $81 \mathrm{~kb}$ )

\section{Competing interests}

DHS has equity in Hercules Pharmaceuticals, BV, which is studying AHR inhibitors as therapeutics. No other authors have a competing interest.

\section{Authors' contributions}

With DHS, EAS conceived and designed experiments, executed the experiments and analyzed data, drafted the manuscript, and critically reviewed the manuscript. $Z W$ and $O N$ substantially helped in the design and interpretation of the research, and revised the manuscript critically for important intellectual content. FM and SM carried out the computational analysis and contributed to the drafting of the manuscript. BWS and GJM participated in the design of the study, provided expertise for stem cell assays, and critically reviewed the manuscript. EBL performed immunohistochemistry and immunofluorescence studies. DHS conceived and designed experiments, analyzed data, interpreted outcomes, drafted and critically reviewed the manuscript. All authors read and approved the final manuscript for publication and agree to be accountable for all aspects of the work in ensuring that questions related to the accuracy or integrity of any part of the work are appropriately investigated and resolved.

\section{Acknowledgements}

Supported by P42ES007381, PO1 ES011624, The Art beCAUSE Breast Cancer Foundation, The Mary Kay Foundation, and the Avon Foundation. This publication was developed under STAR Fellowship Assistance Agreement no. FP-917648-01-0 awarded by the U.S. Environmental Protection Agency (EPA). It has not been formally reviewed by EPA. The views expressed in this publication are solely those of Elizabeth Stanford, and EPA does not endorse any products or commercial services mentioned in this publication. The authors would like to acknowledge Ms. B. Campbell for her technical assistance, Dr. J. Weinberg for statistical consultations, Dr. M. Pollastri for synthesizing FICZ and $\mathrm{CH} 223191$, Dr. M. Denison for his gift of the pGudLuc vector, Dr. S. Ethier for the Sum 149 cells, the Boston University Flow Cytometry Core Facility for their support and assistance, Dr. Michael Kirber and the BUMC Cellular Imaging, and Ms. Nathalie Bitar in the Boston University Immunohistochemistry Core Facility. Finally, we would like to thank Dr. Ana De La Cueva Herrera for her assistance with mammary fat pad injections.

\section{Author details}

'Department of Environmental Health, Boston University School of Public Health, 72 East Concord Street (R-408), Boston, Massachusetts 02118, USA. ${ }^{2}$ Boston University Molecular and Translational Medicine Program, $72 \mathrm{E}$. Concord Street, Boston, MA 02118, USA. ${ }^{3}$ Department of Medicine, Boston University School of Medicine, Section of Computational Biomedicine, Boston, MA 02118, USA. ${ }^{4}$ Department of Medicine, Boston University School of Medicine, Section of Hematology and Oncology, 650 Albany Street, Boston, MA 02118, USA. ${ }^{5}$ Boston University and Boston Medical Center, Center for Regenerative Medicine (CReM), 710 Albany Street, Boston, MA 02118, USA.

Received: 18 October 2015 Accepted: 22 February 2016 Published online: 16 March 2016

\section{References}

1. Leffall L, Kripke M. President's Cancer Panel: 2008-2009 Annual Report Reducing Environmental Cancer Risk. Bethseda, MD: National Cancer Institute; 2010.

2. Benigni R, Bossa C. Mechanisms of chemical carcinogenicity and mutagenicity: a review with implications for predictive toxicology. Chem Rev. 2011;111(4):2507-36. doi:10.1021/cr100222q.

3. Rudel RA, Fenton SE, Ackerman JM, Euling SY, Makris SL. Environmental exposures and mammary gland development: state of the science, public health implications, and research recommendations. Environ Health Perspect. 2011;119(8):1053-61. doi:10.1289/ehp.1002864.

4. Williams DE. The rainbow trout liver cancer model: response to environmental chemicals and studies on promotion and chemoprevention. Comp Biochem Physiol C Toxicol Pharmacol. 2012;155(1):121-7. doi:10.1016/j.cbpc.2011.05.013.

5. Mordukhovich I, Rossner Jr P, Terry MB, Santella R, Zhang YJ, Hibshoosh H, et al. Associations between polycyclic aromatic hydrocarbon-related exposures and p53 mutations in breast tumors. Environ Health Perspect. 2010;118(4):511-8. doi:10.1289/ehp.0901233.

6. Brody JG, Moysich KB, Humblet O, Attfield KR, Beehler GP, Rudel RA Environmental pollutants and breast cancer: epidemiologic studies. Cancer. 2007;109(12 Suppl):2667-711.

7. Eldrige SG, Gould MN, Butterworth BE. Genotoxicity of environmental agents in human mammary epithelial cells. Cancer Res. 2006:4329:1-6.

8. Kewley RJ, Whitelaw ML, Chapman-Smith A. The mammalian basic helixloop-helix/PAS family of transcriptional regulators. Int J Biochem Cell Biol. 2004;36(2):189-204. doi:10.1016/S1357-2725(03)00211-5.

9. Furness SGB, Whelan F. The pleiotropy of dioxin toxicity - Xenobiotic misappropriation of the aryl hydrocarbon receptor \& alternative physiological roles. Pharmacol Ther. 2009;124(3):336-53. doi:10.1016/j. pharmthera.2009.09.004.

10. Schlezinger JJ, Liu D, Farago M, Seldin DC, Belguise K, Sonenshein GE, et al. A role for the aryl hydrocarbon receptor in mammary gland tumorigenesis. Biol Chem. 2006;387(9):1175-87. doi:10.1515/BC.2006.145.

11. Safe $\mathrm{S}$, Lee $\mathrm{SO}$, Jin UH. Role of the aryl hydrocarbon receptor in carcinogenesis and potential as a drug target. Toxicol Sci. 2013;135(1):1-16. doi:10.1093/toxsci/kft128.

12. Brooks J, Eltom S. Malignant transformation of mammary epithelial cells by ectopic overexpression of the aryl hydrocarbon receptor. Curr Cancer Drug Targets. 2011;11:654-69.

13. Goode GD, Ballard BR, Manning HC, Freeman ML, Kang Y, Eltom SE. Knockdown of aberrantly upregulated aryl hydrocarbon receptor reduces tumor growth and metastasis of MDA-MB-231 human breast cancer cell line. Int J Cancer. 2013;133(12):2769-80. doi:10.1002/ijc.28297.

14. Goode G, Pratap S, Eltom SE. Depletion of the aryl hydrocarbon receptor in MDA-MB-231 human breast cancer cells altered the expression of genes in key regulatory pathways of cancer. PLoS One. 2014;9(6):e100103. doi:10.1371/journal.pone.0100103.

15. Yang X, Solomon S, Fraser LR, Trombino AF, Liu D, Sonenshein GE, et al. Constitutive regulation of CYP1B1 by the aryl hydrocarbon receptor (AhR) in pre-malignant and malignant mammary tissue. J Cell Biochem. 2008;104(2):402-17. doi:10.1002/jcb.21630.

16. Chang C, Puga A. Constitutive activation of the aromatic hydrocarbon receptor. Mol Cell Biol. 1998;18(1):525-35.

17. Opitz CA, Litzenburger UM, Sahm F, Ott M, Tritschler I, Trump S, et al. An endogenous tumour-promoting ligand of the human aryl hydrocarbon receptor. Nature. 2011;478(7368):197-203. doi:10.1038/nature10491.

18. Al-Haij M, Wicha MS, Benito-Hernandez A, Morrison S, Clarke MF. Prospective identification of tumorigenic breast cancer cells. Proc Nat Acad Sci. 2003;100(7):3983-8.

19. Charafe-Jauffret E, Ginestier C, lovino F, Tarpin C, Diebel M, Esterni B, et al. Aldehyde dehydrogenase 1-positive cancer stem cells mediate metastasis and poor clinical outcome in inflammatory breast cancer. Clin Cancer Res. 2010;16(1):45-55. doi:10.1158/1078-0432.CCR-09-1630.

20. Charafe-Jauffret E, Ginestier C, lovino F, Wicinski J, Cervera N, Finetti P, et al. Breast cancer cell lines contain functional cancer stem cells with metastatic capacity and a distinct molecular signature. Cancer Res. 2009;69(4):1302-13. doi:10.1158/0008-5472.CAN-08-2741.

21. Economopoulou P, Kaklamani VG, Siziopikou K. The role of cancer $s$ tem cells in breast cancer initiation and progression: potential cancer stem cell-directed therapies. Oncologist. 2012;17(11):1394-401. doi:10.1634/theoncologist.2012-0163. 
22. Gangopadhyay S, Nandy A, Hor P, Mukhopadhyay A. Breast cancer stem cells: A novel therapeutic target. Clin Breast Cancer. 2013;13(1):7-15. doi:10.1016/j.clbc.2012.09.017.

23. Ginestier C, Hur M-H, Charafe-Jauffret E, Monville F, Dutcher J, Brown M, et al. ALDH1 is a marker of normal and malignant human mammary stem cells and a predictor of poor clinical outcome. Cell Stem Cell. 2007;1(5):555-67. doi:10.1016/j.stem.2007.08.014.

24. Lobo NA, Shimono Y, Qian D, Clarke MF. The biology of cancer stem cells. Ann Rev Cell Dev Biol. 2007;23(1):675-99. doi:10.1146/annurev.cellbio.22. 010305.104154.

25. Fischer KR, Durrans A, Lee S, Sheng J, Li F, Wong ST, et al. Epithelial-tomesenchymal transition is not required for lung metastasis but contributes to chemoresistance. Nature. 2015;527(7579):472-6. doi:10.1038/nature15748.

26. Bolós V, Blanco M, Medina V, Aparicio G, Díaz-Prado S, Grande E. Notch signalling in cancer stem cells. Clin Transl Oncol. 2009;11(1):11-9. doi:10.1007/s12094-009-0305-2.

27. Leis O, Eguiara A, Lopez-Arribillaga E, Alberdi MJ, Hernandez-Garcia S, Elorriaga $\mathrm{K}$, et al. Sox2 expression in breast tumours and activation in breast cancer stem cells. Oncogene. 2011;31(11):1354-65. doi:10.1038/onc.2011.338.

28. Mani SA, Guo W, Liao M-J, Eaton EN, Ayyanan A, Zhou AY, et al. The epithelial-mesenchymal transition generates cells with properties of stem cells. Cell. 2008;133(4):704-15. doi:10.1016/j.cell.2008.03.027.

29. Scheel C, Weinberg RA. Cancer stem cells and epithelial-mesenchymal transition: concepts and molecular links. Semin Cancer Biol. 2012;22(5-6): 396-403. doi:10.1016/j.semcancer.2012.04.001.

30. Chiou SH, Wang ML, Chou YT, Chen CJ, Hong CF, Hsieh WJ, et al. Coexpression of Oct4 and Nanog enhances malignancy in lung adenocarcinoma by inducing cancer stem cell-like properties and epithelial-mesenchymal transdifferentiation. Cancer Res. 2010;70(24):10433-44. doi:10.1158/00085472.CAN-10-2638.

31. Wicha M, Dontu G, Al-Hajj M. Stem cells in normal breast development and breast cancer. Cell Prolif. 2003;36:59-72.

32. Tanei T, Morimoto K, Shimazu K, Kim SJ, Tanji Y, Taguchi T, et al. Association of breast cancer stem cells identified by aldehyde dehydrogenase 1 expression with resistance to sequential paclitaxel and epirubicin-based chemotherapy for breast cancers. Clin Cancer Res. 2009;15(12):4234-41. doi:10.1158/1078-0432.CCR-08-1479.

33. Reya T, Morrison SJ, Clarke MF, Weissman IL. Stem cells, cancer, and cancer stem cells. Nature. 2001;414:105-12.

34. Gasiewicz TA, Singh KP, Bennett JA. The Ah receptor in stem cell cycling, regulation, and quiescence. Ann N Y Acad Sci. 2014;1310(1):44-50. doi:10.1111/nyas.12361.

35. Ko C-I, Wang Q, Fan Y, Xia Y, Puga A. Pluripotency factors and Polycomb Group proteins repress aryl hydrocarbon receptor expression in murine embryonic stem cells. Stem Cell Res. 2014;12(1):296-308. doi:10.1016/j.scr.2013.11.007.

36. Singh KP, Bennett JA, Casado FL, Walrath JL, Welle SL, Gasiewicz TA. Loss of aryl hydrocarbon receptor promotes gene changes associated with premature hematopoietic stem cell exhaustion and development of a myeloproliferative disorder in aging mice. Stem Cells Dev. 2014;23(2):95-106. doi:10.1089/scd.2013.0346.

37. Singh KP, Garrett RW, Casado FL, Gasiewicz TA. Aryl hydrocarbon receptornull allele mice have hematopoietic stem/progenitor cells with abnormal characteristics and functions. Stem Cells Dev. 2011;20(5):769-84. doi:10. 1089/scd.2010.0333.

38. Wang Q, Chen J, Ko C-I, Fan Y, Carreira V, Chen Y, et al. Disruption of aryl hydrocarbon receptor homeostatic levels during embryonic stem cell differentiation alters expression of homeobox transcription factors that control cardiomyogenesis. Environ Health Perspect. 2013;121(11-12):133443. doi:10.1289/ehp.1307297.

39. Smith BW, Rozelle SS, Leung A, Ubellacker J, Parks A, Nah SK, et al. The aryl hydrocarbon receptor directs hematopoietic progenitor cell expansion and differentiation. Blood. 2013;122(3):376-85. doi:10.1182/blood-2012-11-466722.

40. Latchney S, Lioy D, Henry E, Gasiewicz TA, Strathmann F, Mayer-Proschel M, et al. Neural precursor cell proliferation Is disrupted through activation of the aryl hydrocarbon receptor by 2,3,7,8-tetrachlorodibenzo-p-dioxin. Stem Cells Dev. 2011:20:1-14.

41. Abdelrahim M, Smith 3rd R, Safe S. Aryl hydrocarbon receptor gene silencing with small inhibitory RNA differentially modulates Ah-responsiveness in MCF-7 and HepG2 cancer cells. Mol Pharmacol. 2003;63(6):1373-81.

42. Parks AJ, Pollastri MP, Hahn ME, Stanford EA, Novikov O, Franks DG, et al. In silico identification of an aryl hydrocarbon receptor (AHR) antagonist with biological activity in vitro and in vivo. Mol Pharmacol. 2014;86(5):593-608. doi:10.1124/mol.114.093369.

43. Quadri S, Qadri A, Hahn M, Mann K, Sherr D. The bioflavonoid galangin blocks aryl hydrocarbon receptor activation and polycyclic aromatic hydrocarbon-induced pre-B cell apoptosis. Mol Pharmacol. 2000;58(3):515-25.

44. Trombino A, Near R, Matulka RA, Yang S, Hafer L, Toselli P, et al. Expression of the aryl hydrocarbon receptor/transcription factor (AhR) and AhRregulated CYP1. Breast Cancer Res Treat. 2000;63:117-31.

45. Murray SA, Yang S, Demicco E, Ying H, Sherr DH, Hafer LJ, et al. Increased expression of MDM2, cyclin D1, and p27(Kip1) in carcinogen-induced rat mammary tumors. J Cell Biochem. 2005;95(5):875-84.

46. Currier N, Solomon SE, Demicco EG, Chang DL, Farago $M$, Ying $H$, et al. Oncogenic signaling pathways activated in DMBA-induced mouse mammary tumors. Toxicol Pathol. 2005;33(6):726-37. doi:10.1080/ 01926230500352226

47. Hall JM, Barhoover MA, Kazmin D, McDonnell DP, Greenlee WF, Thomas RS. Activation of the aryl-hydrocarbon receptor inhibits invasive and metastatic features of human breast cancer cells and promotes breast cancer cell differentiation. Mol Endocrinol. 2010;24(2):359-69. doi:10.1210/me.2009-0346.

48. Dalerba P, Cho RW, Clarke MF. Cancer stem cells: models and concepts. Annu Rev Med. 2007;58(1):267-84. doi:10.1146/annurev.med.58.062105.204854

49. Magee JA, Piskounova E, Morrison SJ. Cancer stem cells: impact, heterogeneity, and uncertainty. Cancer Cell. 2012;21(3):283-96. doi:10.1016/j.ccr.2012.03.003.

50. Tang B, Raviv A, Esposito D, Flanders KC, Daniel C, Nghiem BT, et al. A flexible reporter system for direct observation and isolation of cancer stem cells. Stem Cell Rep. 2015;4(1):155-69. doi:10.1016/j.stemcr.2014.11.002.

51. Visvader JE, Lindeman GJ. Cancer stem cells: current status and evolving complexities. Cell Stem Cell. 2012;10(6):717-28. doi:10.1016/j.stem.2012.05.007.

52. Croker AK, Goodale D, Chu J, Postenka C, Hedley BD, Hess DA, et al. High aldehyde dehydrogenase and expression of cancer stem cell markers selects for breast cancer cells with enhanced malignant and metastatic ability. J Cell Mol Med. 2009;13(8b):2236-52. doi:10.1111/j.1582-4934.2008.00455.x

53. Croker AK, Allan AL. Inhibition of aldehyde dehydrogenase (ALDH) activity reduces chemotherapy and radiation resistance of stem-like ALDHhiCD44+ human breast cancer cells. Breast Cancer Res Treat. 2011;133(1):75-87. doi:10.1007/s10549-011-1692-y.

54. Choi EY, Lee H, Dingle RWC, Kim KB, Swanson HI. Development of novel $\mathrm{CH} 223191$-based antagonists of the aryl hydrocarbon receptor. Mol Pharmacol. 2011;81(1):3-11. doi:10.1124/mol.111.073643.

55. Kim SH, Henry EC, Kim DK, Kim YH, Shin KJ, Han MS, et al. Novel compound 2-methyl-2H-pyrazole-3-carboxylic acid (2-methyl-4-otolylazo-phenyl)-amide (CH-223191) prevents 2,3,7,8-TCDD-Induced toxicity by antagonizing the aryl hydrocarbon receptor. Mol Pharmacol. 2006;69(6):1871-8. doi:10.1124/mol.105.021832.

56. Jönsson M, Franks D, Woodin B, Jenny M, Garrick R, Behrendt L, et al. The tryptophan photoproduct 6-formylindolo[3,2-b]carbazole (FICZ) binds multiple AHRs and induces multiple CYP1 genes via AHR2 in zebrafish. Chem Biol Interact. 2009;181(3):447-54. doi:10.1016/j.cbi.2009.07.003.

57. Holliday D, Speirs V. Choosing the right cell line for breast cancer research. Breast Cancer Res. 2011:13(215):1-7.

58. Chaffer CL, Brueckmann I, Scheel C, Kaestli AJ, Wiggins PA, Rodrigues LO, et al. Normal and neoplastic nonstem cells can spontaneously convert to a stem-like state. Proc Nat Acad Sci U S A. 2011;108(19):7950-5. doi:10.1073/pnas.1102454108.

59. Watson JD, Prokopec SD, Smith AB, Okey AB, Pohjanvirta R, Boutros PC. TCDD dysregulation of 13 AHR-target genes in rat liver. Toxicol Appl Pharmacol. 2014;274(3):445-54. doi:10.1016/j.taap.2013.12.004.

60. Forghanifard MM, Ardalan Khales S, Javdani-Mallak A, Rad A, Farshchian M, Abbaszadegan MR. Stemness state regulators SALL4 and SOX2 are involved in progression and invasiveness of esophageal squamous cell carcinoma. Med Oncol. 2014;31(4):922. doi:10.1007/s12032-014-0922-7.

61. Lengerke $C$, Fehm T, Kurth $R$, Neubauer H, Scheble V, Müller F, et al. Expression of the embryonic stem cell marker SOX2 in early-stage breast carcinoma. BMC Cancer. 2011;11:42. doi:10.1186/1471-2407-11-42.

62. Liang S, Furuhashi M, Nakane R, Nakazawa S. Hamada J-i, lizasa H. Isolation and characterization of human breast cancer cells with SOX2 promoter activity. Biochem Biophys Res Commun. 2013:437(2):205-11. doi:10.1016/j.bbrc.2013.06.038.

63. Rodriguez-Pinilla SM, Sarrio D, Moreno-Bueno G, Rodriguez-Gil Y, Martinez MA, Hernandez L, et al. Sox2: a possible driver of the basal-like 
phenotype in sporadic breast cancer. Mod Pathol. 2007;20(4):474-81. doi:10.1038/modpathol.3800760.

64. Ling $G Q$, Chen $D B$, Wang $B Q$, Zhang $L S$. Expression of the pluripotency markers Oct3/4, Nanog and Sox2 in human breast cancer cell lines. Oncol Lett. 2012;4(6):1264-8. doi:10.3892/ol.2012.916.

65. Raimondi C, Gradilone A, Naso G, Vincenzi B, Petracca A, Nicolazzo C, et al. Epithelial-mesenchymal transition and stemness features in circulating tumor cells from breast cancer patients. Breast Cancer Res Treat. 2011; 130(2):449-55. doi:10.1007/s10549-011-1373-X.

66. Barretina J, Caponigro G, Stransky N, Venkatesan K, Margolin AA, Kim S, et al. The Cancer Cell Line Encyclopedia enables predictive modelling of anticancer drug sensitivity. Nature. 2012;483(7391):603-7. doi:10.1038/nature11003.

67. Shehin SE, Stephenson RO, Greenlee WF. Transcriptional regulation of the human CYP1B1 gene. Evidence for involvement of an aryl hydrocarbon receptor response element in constitutive expression. J Biol Chem. 2000; 275(10):6770-6.

68. Ma CX, Ellis MJ. The Cancer Genome Atlas: clinical applications for breast cancer. Oncology. 2013;27(12):1263-9.

69. Curtis C, Shah SP, Chin SF, Turashvili G, Rueda OM, Dunning MJ, et al. The genomic and transcriptomic architecture of 2,000 breast tumours reveals novel subgroups. Nature. 2012;486(7403):346-52. doi:10.1038/nature10983.

70. Dontu G, Wicha MS. Survival of mammary stem cells in suspension culture: implications for stem cell biology and neoplasia. J Mammary Gland Biol Neoplasia. 2005;10(1):75-86. doi:10.1007/s10911-005-2542-5.

71. Ponti D, Zaffaroni N, Capelli C. Breast cancer stem cells: an overview. Eur J Cancer. 2006;42(9):1219-24

72. Fillmore CM, Kuperwasser C. Human breast cancer cell lines contain stemlike cells that self-renew, give rise to phenotypically diverse progeny and survive chemotherapy. Breast Cancer Res. 2008;10(2):R25. doi:10.1186/bcr1982.

73. Li HZ, Yi TB, Wu ZY. Suspension culture combined with chemotherapeutic agents for sorting of breast cancer stem cells. BMC Cancer. 2008:8:135. doi:10.1186/1471-2407-8-135.

74. Gonzalez-Angulo AM, Hennessy BT, Broglio K, Meric-Bernstam F, Cristofanilli $\mathrm{M}$, Giordano SH, et al. Trends for inflammatory breast cancer: is survival improving? Oncologist. 2007;12(8):904-12. doi:10.1634/theoncologist.12-8-904.

75. Clevers $\mathrm{H}$. The cancer stem cell: premises, promises and challenges. Nat Med. 2011;17(3):313-9. doi:10.1038/nm.2304.

76. Qiu M, Peng Q, Jiang I, Carroll C, Han G, Rymer I, et al. Specific inhibition of Notch1 signaling enhances the antitumor efficacy of chemotherapy in triple negative breast cancer through reduction of cancer stem cells. Cancer Lett. 2013;328(2):261-70. doi:10.1016/j.canlet.2012.09.023.

77. Bekki K, Vogel H, Li W, Ito T, Sweeney C, Haarmann-Stemmann T, et al. The aryl hydrocarbon receptor (AhR) mediates resistance to apoptosis induced in breast cancer cells. Pestic Biochem Physiol. 2015;120:5-13. doi:10.1016/j. pestbp.2014.12.021.

78. Raha D, Wilson TR, Peng J, Peterson D, Yue P, Evangelista M, et al. The cancer stem cell marker aldehyde dehydrogenase is required to maintain a drug-tolerant tumor cell subpopulation. Cancer Res. 2014;74(13):3579-90. doi:10.1158/0008-5472.CAN-13-3456

79. Kim DW, Gazourian L, Quadri SA, Romieu-Mourez R, Sherr DH, Sonenshein GE. The RelA NF-KB subunit and the aryl hydrocarbon receptor (AhR) cooperate to transactivate the c-myc promoter in mammary cells. Oncogene. 2000;19(48):5498-506

80. Boitano A, Wang J, Romeo R, Bouchez L, Parker A, Sutton S, et al. Ary hydrocarbon receptor antagonists promote the expansion of human hematopoietic stem cells. Science. 2010;329(5997):1345-8. doi:10.1126/ science.1191536.

81. Simmons MJ, Serra R, Hermance N, Kelliher MA. NOTCH1 inhibition in vivo results in mammary tumor regression and reduced mammary tumorsphere forming activity in vitro. Breast Cancer Res. 2012;14(5):R126. doi:10.1186/bcr3321.

82. Hombach-Klonisch S, Paranjothy T, Wiechec E, Pocar P, Mustafa T, Seifert A, et al. Cancer stem cells as targets for cancer therapy: selected cancers as examples. Arch Immunol Ther Exp. 2008;56(3):165-80. doi:10.1007/s00005-008-0023-4.

83. Park I-K, Morrison SJ, Clarke MF. Bmi1, stem cells, and senescence regulation. J Clin Investig. 2004;113(2):175-9. doi:10.1172/JCI200420800.

84. Paranjape A, Balaji S, Mandal T, Krushik E, Nagaraj P, Mukherjee G, et al. Bmi1 regulates self-renewal and epithelial to mesenchymal transition in breast cancer cells through Nanog. BMC Cancer. 2014;14:785.
85. Ezeh UI, Turek PJ, Reijo RA, Clark AT. Human embryonic stem cell genes OCT4, NANOG, STELLAR, and GDF3 are expressed in both seminoma and breast carcinoma. Cancer. 2005;104(10):2255-65. doi:10.1002/cncr.21432.

86. Takahashi K, Yamanaka S. Induction of pluripotent stem cells from mouse embryonic and adult fibroblast cultures by defined factors. Cell. 2006;126(4): 663-76. doi:10.1016/j.cell.2006.07.024

87. Battula VL, Evans KW, Hollier BG, Shi Y, Marini FC, Ayyanan A, et al. Epithelialmesenchymal transition-derived cells exhibit multilineage differentiation potential similar to mesenchymal stem cells. Stem Cells. 2010;28(8):1435-45. doi:10.1002/stem.467.

88. Morel A-P, Lièvre M, Thomas C, Hinkal G, Ansieau S, Puisieux A. Generation of breast cancer stem cells through epithelial-mesenchymal transition. PLoS One. 2008;3(8):e2888. doi:10.1371/journal.pone.0002888.g005.

89. Maecker B, Sherr D, Vonderheide R, von Bergwelt-Baildon M, Hirano N, Anderson $\mathrm{K}$, et al. The shared tumor-associated antigen cytochrome P450 1B1 is recognized by specific cytotoxic T cells. Blood. 2003;102(9):3287-94. doi:10.1182/blood-2003-05-1374.

90. Shatalova EG, Klein-Szanto AJ, Devarajan K, Cukierman E, Clapper ML. Estrogen and cytochrome P450 1B1 contribute to both early-and late-stage head and neck carcinogenesis. Cancer Prev Res (Phila). 2011;4(1):107-15. doi:10.1158/1940-6207.CAPR-10-0133.

91. Wincent E, Bengtsson J, Bardbori A, Alsberg T, Luecke S, Rannug U, et al. Inhibition of cytochrome P4501-dependent clearance of the endogenous agonist FICZ as a mechanism for activation of the aryl hydrocarbon receptor. PNAS. 2012;109(2):4479-84.

92. Barhoover MA, Hall JM, Greenlee WF, Thomas RS. Aryl hydrocarbon receptor regulates cell cycle progression in human breast cancer cells via a functional interaction with cyclin-dependent kinase 4. Mol Pharmacol. 2010; 77(2):195-201. doi:10.1124/mol.109.059675.

93. Chang JT, Chang H, Chen PH, Lin SL, Lin P. Requirement of aryl hydrocarbon receptor overexpression for CYP1B1 up-Regulation and cell growth in human lung adenocarcinomas. Clin Cancer Res. 2007;13(1):38-45. doi:10.1158/1078-0432.CCR-06-1166.

94. Powell JB, Goode GD, Eltom SE. The anyl hydrocarbon receptor: a target for breast cancer therapy. J Cancer Ther. 2013;4(7):1177-86. doi:10.4236/jct.2013.47137.

95. Opitz CA, Litzenburger UM, Opitz U, Sahm F, Ochs K, Lutz C, et al. the indoleamine-2,3-dioxygenase (IDO) inhibitor 1-methyl-d-tryptophan upregulates IDO1 in human cancer cells. PLoS One. 2011;6(5):e19823. doi:10. 1371/journal.pone.0019823.g008.

96. Zhao S, Kanno Y, Nakayama M, Makimura M, Ohara S, Inouye Y. Activation of the aryl hydrocarbon receptor represses mammosphere formation in MCF-7 cells. Cancer Lett. 2012;317(2):192-8. doi:10.1016/j.canlet.2011.11.025.

97. Zhao S, Ohara S, Kanno Y, Midorikawa Y, Nakayama M, Makimura M, et al. HER2 overexpression-mediated inflammatory signaling enhances mammosphere formation through up-regulation of aryl hydrocarbon receptor transcription. Cancer Lett. 2013;330(1):41-8. doi:10.1016/..canlet.2012.11.021.

98. Murray IA, Patterson AD, Perdew GH. Aryl hydrocarbon receptor ligands in cancer: friend and foe. Nat Rev Cancer. 2014;14(12):801-14. doi:10.1038/nrc3846.

99. Prud'homme G, Glinka Y, Toulina A, Ace O, Subramaniam V, Jothy S. Breast cancer stem-like cells are inhibited by a non-toxic aryl hydrocarbon receptor agonist. PLoS One. 2010;5(11):e13831. doi:10.1371/journal.pone.0013831.

100. Subramaniam V, Ace O, Prud'homme GJ, Jothy S. Tranilast treatment decreases cell growth, migration and inhibits colony formation of human breast cancer cells. Exp Mol Pathol. 2011;90(1):116-22. doi:10.1016/j.yexmp.2010.10.012.

101. Howard G, Schlezinger J, Hahn M, Webster T. Generalized concentration addition predicts joint effects of aryl hydrocarbon receptor agonists with partial agonists and competitive antagonists. Environ Health Perspect. 2010; 118(5):666-72. doi:10.1289/ehp.0901312.

102. Dubrovska A, Hartung A, Bouchez LC, Walker JR, Reddy VA, Cho CY, et al. CXCR4 activation maintains a stem cell population in tamoxifen-resistant breast cancer cells through AhR signalling. Br J Cancer. 2012;107(1):43-52. doi:10.1038/bjc.2012.105.

103. Pfaffl M. A new mathematical model for relative quantification in real-time RT-PCR. Nucleic Acids Res. 2001;29(9):e45.

104. Taylor RT, Wang F, Hsu EL, Hankinson O. Roles of coactivator proteins in dioxin induction of CYP1A1 and CYP1B1 in human breast cancer cells. Toxicol Sci. 2009;107(1):1-8. doi:10.1093/toxsci/kfn217. 